Reactor Engineering

Division

Reactor Engineering

Division

Reactor Engineering

Division

Reactor Engineering

Division

Reactor Engineering

Division

Reactor Engineering

Division

Reactor Engineering

Division

Reactor Engineering

Division

Reactor Engineering

Division

\title{
DIRECT CONTAINMENT HEATING EXPERIMENTS IN ZION NUCLEAR POWER PLANT GEOMETRY USING PROTOTYPIC CORE MATERIALS
}

The U2 Test

By J. L. Binder, L. M. McUmber, and B. W. Spencer

Reactor Engineering

Division

Reactor Engineering

Division

Reactor Engineering

Division

Reactor Engineering

Division

Reactor Engineering

Division

Reactor Engineering

Division

Reactor Engineering

Division

Reactor Engineering

Division

Reactor Engineering

Division

Reactor Engineering

Division

Reactor Engineering

Division

Reactor Engineering

Division

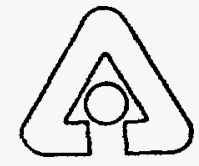

Argonne National Laboratory, Argonne, Illinois 60439

operated by the University of Chicago for the

United States Department of Energy under Contract

W-31-109-Eng-38 
Argonne National Laboratory, with facilities in the states of Illinois and Idaho, is owned by United States government, and operated by The University of Chicago under the provisions of a contract with the Department of Energy.

This report was prepared as an account of work sponsored by an agency of the United States Government. Neither the United States Government nor any agency thereof, nor any of their employees, makes any warranty, express or implied, or assumes any legal liability or responsibility for the accuracy, completeness, or usefulness of any information, apparatus, product, or process disclosed, or represents that its use would not infringe privately owned rights. Reference herein to any specific commercial product, process, or service by trade name, trademark, manufacturer, or otherwise, does not necessarily constitute or imply its endorsement, recommendation, or favoring by the United States Government or any agency thereof. The views and opinions of authors expressed herein do not necessarily state or reflect those of the United States Government or any agency thereof. 


\section{DISCLAIMER}

Portions of this document may be illegible in electronic image products. Images are produced from the best available original document. 
DIRECT CONTAINMENT HEATING EXPERIMENTS IN ZION NUCLEAR POWER PLANT GEOMETRY USING PROTOTYPIC CORE MATERIALS

The U2 Test

by

J. L. Binder

L. M. McUmber

B. W. Spencer

Engineering Development Laboratories

Reactor Engineering Division

Argonne National Laboratory

9700 South Cass Avenue

Argonne, Illinois 60439

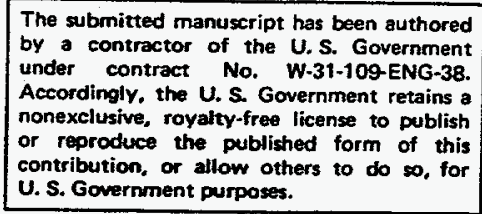

U. S. Government purposes.

May 1993 


\section{Direct Containment Heating Experiments in Zion Nuclear}

Power Plant Geometry Using Prototypic Core Materials

The U2 Test

by

J. L. Binder, L. M. McUmber and B. W. Spencer

\section{ABSTRACT}

A third Direct Containment Heating (DCH) experiments has been completed which utilizes prototypic core materials. The reactor material tests are a follow on to the Integral Effects Testing (IET) DCH program. The IET series of tests primarily addressed the effect of scale on DCH phenomena. This was accomplished by completing a series of counterpart tests in $1 / 40$ and $1 / 10$ th linear scale DCH facilities at Argonne National Laboratory (ANL) and Sandia National Laboratories (SNL), respectively. The IET experiments modeled the Zion Nuclear Power Plant Geometry. The scale models included representations of the primary system volume, RPV lower head, cavity and instrument tunnel, and the lower containment structures. The experiments were steam driven at nominally 6.2 $\mathrm{MPa}$. Iron-alumina thermite with chromium was used as a core melt simulant in the IET experiments. While the IET experiments at ANL and SNL provided useful data on the effect of scale on DCH phenomena, a significant question concerns the potential experiment distortions introduced by the use of non-prototypic iron/alumina thermite. Therfore, further testing with prototypic materials has been carried out at ANL.

A prototypic core melt was produced for the experiment by first mixing powders of uranium, zirconium, iron oxide $\left(\mathrm{Fe}_{2} \mathrm{O}_{3}\right)$, and chromium trioxide $\left(\mathrm{CrO}_{3}\right)$. When ignited the powders react exothermically to produce a molten mixture. The amounts of each powder were selected to produce the anticipated composition for a core melt following a station blackout: $57.8 \mathrm{mass}_{\mathrm{U}} \mathrm{UO}_{2}, 10.5 \mathrm{mass} \% \mathrm{ZrO}_{2}, 14.3$ mass\% $\mathrm{Fe}, 13.7$ mass\% $\mathrm{Zr}$, and 3.7 mass\% $\mathrm{Cr}$. Development tests measured the initial melt temperature to be in the range of $2600-2700 \mathrm{~K}$. The total thermal specific energy content of the melt at $2700 \mathrm{~K}$ is $1.2 \mathrm{MJ} / \mathrm{kg}$ compared to $2.25 \mathrm{MJ} / \mathrm{kg}$ for the iron-alumina simulant at its measured initial temperature of $2500 \mathrm{~K}$. The initial mass of melt $(1.13 \mathrm{~kg})$ was selected to match the total possible energy input of the simulant $(0.713 \mathrm{~kg})$ used in the IET tests. The energy sources include the thermal energy in the melt and also the energy resulting from 
chemical reactions. While the total overall energy content for the two materials is the same, a larger fraction of the energy comes from chemical reactions for the case of prototypic core material.

The test $U 2$ is reported on here and is a counterpart to ANL IET-6. The containment atmosphere for these tests were specified in order to investigate the combustion of pre-existing hydrogen and hydrogen produced in metal-steam reactions. The atmosphere for U2 contained $11.6 \mathrm{mole \%}$ oxygen, $84.6 \mathrm{mole \%}$ nitrogen and $2.6 \mathrm{~mole} \%$ hydrogen. The driving pressure was $4.25 \mathrm{MPa}$ compared to $6.6 \mathrm{MPa}$ for IET-6. The peak containment pressure measured in U2 was $186 \mathrm{kPa}$ compared to $250 \mathrm{kPa}$ for IET-6. 
CONTENTS

ABSTRACT

Page

ACKNOWLEDGEMENTS

I. INTRODUCTION

II. EXPERIMENT DESCRIPTION

A. Facility Description

B. Zion Cavity and Subcompartment Models

C. Instrumentation

1. Pressure Measurements

2. Temperature Measurements

a. Subcompartment and Expansion Vessel Temperatures

b. Cavity Gas Temperature

3. Melt Ejection Indication

4. Data Acquisition

5. Gas Composition Measurements

6. Debris Recovery

D. Test Procedures

1. Pre-test Operations

2. Test Operations

3. Post-test Operations

E. Corium Characterization

2-15

1. Prototype Core Melt Composition

$2-15$

2. Experiment Simulant

2-16

3. Scaling Considerations

$2-20$

III. TEST SPECIFICATIONS AND INITIAL CONDITIONS

A. Thermite Charge

B. Expansion Vessel Atmosphere

C. Cavity Water

D. Hole Diameter

E. Driving Steam Pressure 


\section{CONTENTS (Cont'd.)}

IV. EXPERIMENTAL RESULTS

Page

A. Blowdown History

4-1

B. Pressure Measurements

$4-1$

C. Temperature Measurements

4-4

D. Gas Sample Measurements

4-4

E. Debris Disposition

4-9

4-14

v. ENERGY BALANCE AND PRESSURIZATION EFFICIENCY

5-1

VI. SUMMARY

6-1

VII. REFERENCES

7-1 


\section{LIST OF FIGURES}

Figure

Page

2.1 The Corium Ex-Vessel Interaction (COREXIT) Facility.

2.2 Zion Cavity Model.

2.3 Internal Cavity Surfaces and Dimensions.

2.4 Details of the Melt Generator and Injector (MGI).

2.5 Zion Subcompartment Model.

2.6 Zion Cavity and Subcompartment Model Showing Instrument Locations.

2.7 Aspirated Thermocouple Assembly.

2.8 Experimental Corium Temperature Measured by Thermocouples.

2.9 Experimental Corium Temperature Measured by a Pyrometer.

2.10 Prototype Core Melt and Experiment Simulant Enthalpies.

2.11 Zion NPP Response.

2.12 Melt Mass Scaling for $\mathrm{Fe} / \mathrm{Al}_{2} \mathrm{O}_{3} \mathrm{w} / \mathrm{Cr}$.

2.13 Melt Mass Scaling for Experimental Corium.

4.1 Blowdown History for U2.

4.2 Blowdown History for U2 and IET-6.

4.3 Containment Pressure for U2 and IET-6.

4.4 Dimensionless Containment Pressure.

4.5 Cavity Pressure for U2.

4.6 Subcompartment Gas Temperatures for U2.

4.7 Containment Gas Temperatures for U2.

4.8 Hydrogen and Oxygen Concentrations.

4.9 Hydrogen and Oxygen Moles. 


\section{LIST OF TABLES}

Table

Page

2.1 Instrumentation

2.2 Gas Bottle Locations and Timing.

2.3 Synthesized Melt Composition for an Instrument Tube Penetration Failure at Surry from Levy (1991).

2.4 Summary of Core Melt and Simulant Compositions (mass fraction).

$2-16$

2.5 Oxidation Characteristics of Melt Simulants with Steam.

2.6 Assumed Initial Conditions Used in Melt Mass Scaling.

2-28

2.7 Required Melt Mass to Satisfy Energy/Volume Scaling

2.8 Fractional Contribution to DCH Load

3.1 Initial Conditions.

4.1 Results of Gas Bottle Analysis for U2.

4.2 Debris Recovery Results.

5.1 Energy Balance and Pressurization Efficiency.

6.1 Summary of Test Results. 


\section{ACKNOWLEDGEMENTS}

This work was sponsored by the Nuclear Regulatory Commission under FIN No. A22669. The NRC project manager is Dr. R. Lee. The work of R. Wesel was instrumental in carrying out the experiment. R. Aeschlimann also assisted in carrying out the experiment. Dr. L. Baker provided his insight and expertise into interpreting the corium composition and temperature data. Chemical analyses of the gas samples was carried out by A. Engelkemier of the Analytical Chemistry Laboratory at Argonne National Laboratory. The manuscript was prepared by L. J. Ondracek. 


\section{INTRODUCTION}

The effects of scale on Direct Containment Heating phenomena have been investigated in a counterpart integral testing program conducted simultaneously at Argonne National Laboratory (ANL) and Sandia National Laboratories (SNL). A series of experiments were performed, which simulated a high pressure melt ejection (HPME) in the Zion Nuclear Power Plant (NPP) geometry, in 1/40th and $1 / 10$ th linear scale facilities at ANL and SNL, respectively. The tests were denoted the Integral Effects Test (IET) series. These tests employed ironalumina thermite with additional chromium as the core melt simulant. While the IET experiments provided useful data on the effect of scale on DCH phenomena, a significant question concerns the potential experiment distortions introduced by the use of non-prototypic core melt simulant such as iron/alumina thermite. Therefore, further testing at ANL is being carried out with prototypic materials. This data reports on the third experiment $\mathrm{DCH}-\mathrm{U} 2$.

The objective of the DCH-U2 experiment was to carry out a counterpart experiment to the ANL IET- 6 experiment. The test was specified with containment atmosphere containing oxygen and pre-existing hydrogen. DCH-U2 was successfully carried out on March 11, 1993. 


\section{EXPERIMENT DESCRIPTION}

A. Facility Description

The experiments were conducted in the Corium Ex-Vessel Interaction (COREXIT) facility at Argonne National Laboratory. A schematic of the experiment apparatus is shown in Figure 2.1. Major components of the facility include an explosion resistant containment cell, a $1.51 \mathrm{~m}^{3}$ expansion vessel (EV) and a high pressure steam boiler. The containment cell is designed to withstand shock waves and missiles generated by steam explosions with an equivalent energy release of $0.4 \mathrm{lbm}$ of TNT. For reactor material experiments the cell is sealed except for a vent which is connected to a Venturi Scrubber, HEPA filter and the building exhaust. The expansion vessel stands approximately 3.4 meters high and is 0.76 meters in diameter. The vessel is pressure rated to $150 \mathrm{psi}$. The vessel is trace heated and insulated. The vessel can accommodate a steam atmosphere when required. The 25 gallon boiler was manufactured by Precision Parts Incorporated in Morristown, TN, and is capable of delivering saturated high pressure steam up to $1600 \mathrm{psi}$ at a rate of $150 \mathrm{lb} / \mathrm{hr}$.

The steam delivery system consists of an accumulator (RCS) volume and a pneumatically actuated ball valve designed for high pressure steam. The accumulator, valve and all piping in the steam delivery system are heated and insulated. The accumulator can be safely pressurized up to $9.6 \mathrm{MPa}$.

\section{B. Zion Cavity and Subcompartment Models}

The 2.55\% 1 inear scale Zion cavity was designed and built from drawings supplied by the SNL DCH team. A schematic of the cavity is shown in Figure 2.2. Figure 2.3 shows two views of internal surfaces of the cavity. A table is included which gives the relevant dimensions. The concrete cavity model which is contained within an outer pipe body. The cavity model can withstand pressures of up to $4000 \mathrm{psi}$. Bolted on top of the pipe body is a saddle piece, referred to as the top cap, which contains the melt generator and injector (MGI). The cavity keyway is elongated by a transition chute which connects the cavity to the bottom of the expansion vessel. The elongation is required in order to allow room for the melt generator to fit underneath the expansion vessel. Thus, the keyway is 2.7 times its correctly scaled length. The melt generator was originally designed to contain up to $6 \mathrm{~kg}$ of iron-alumina thermite. It has since 


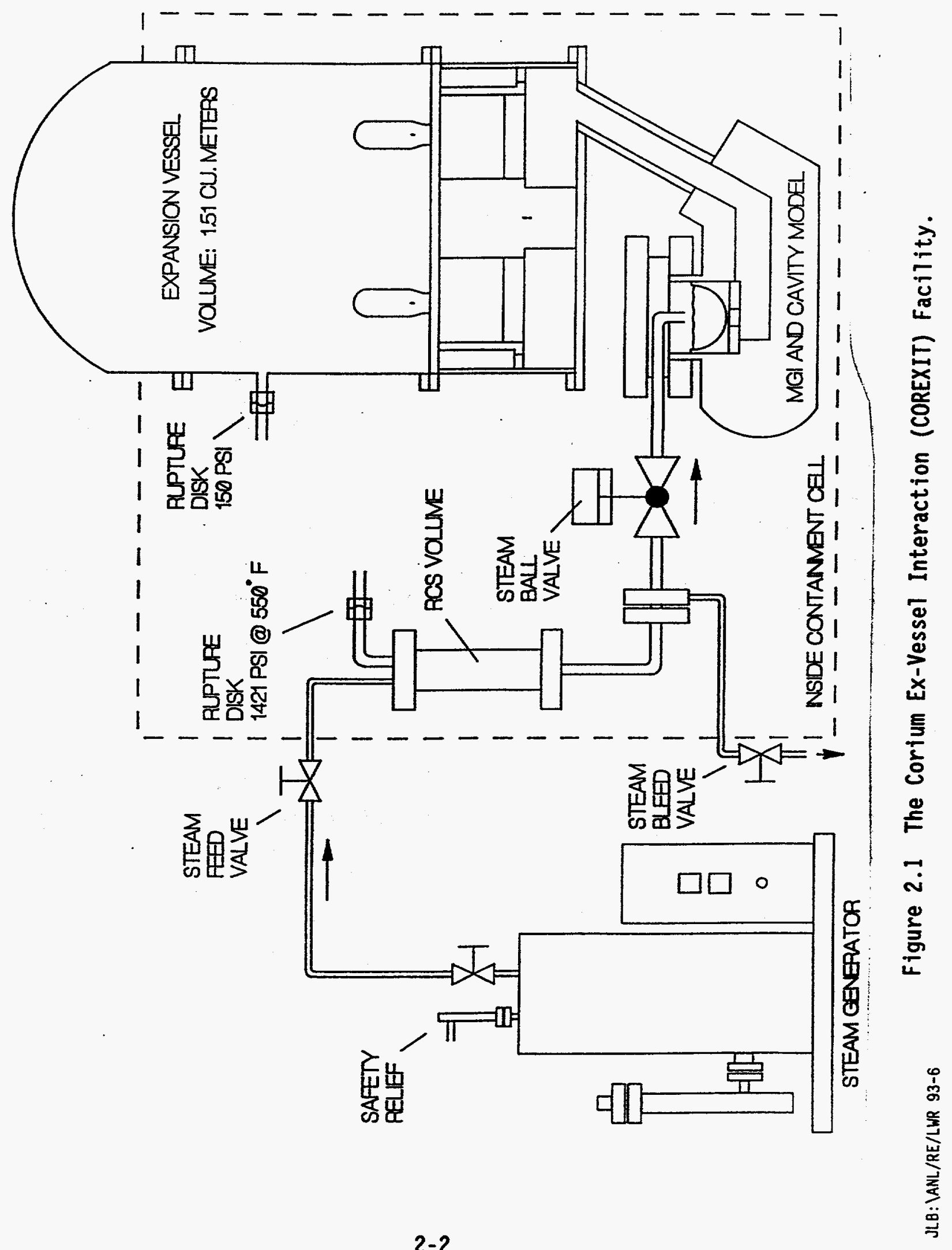




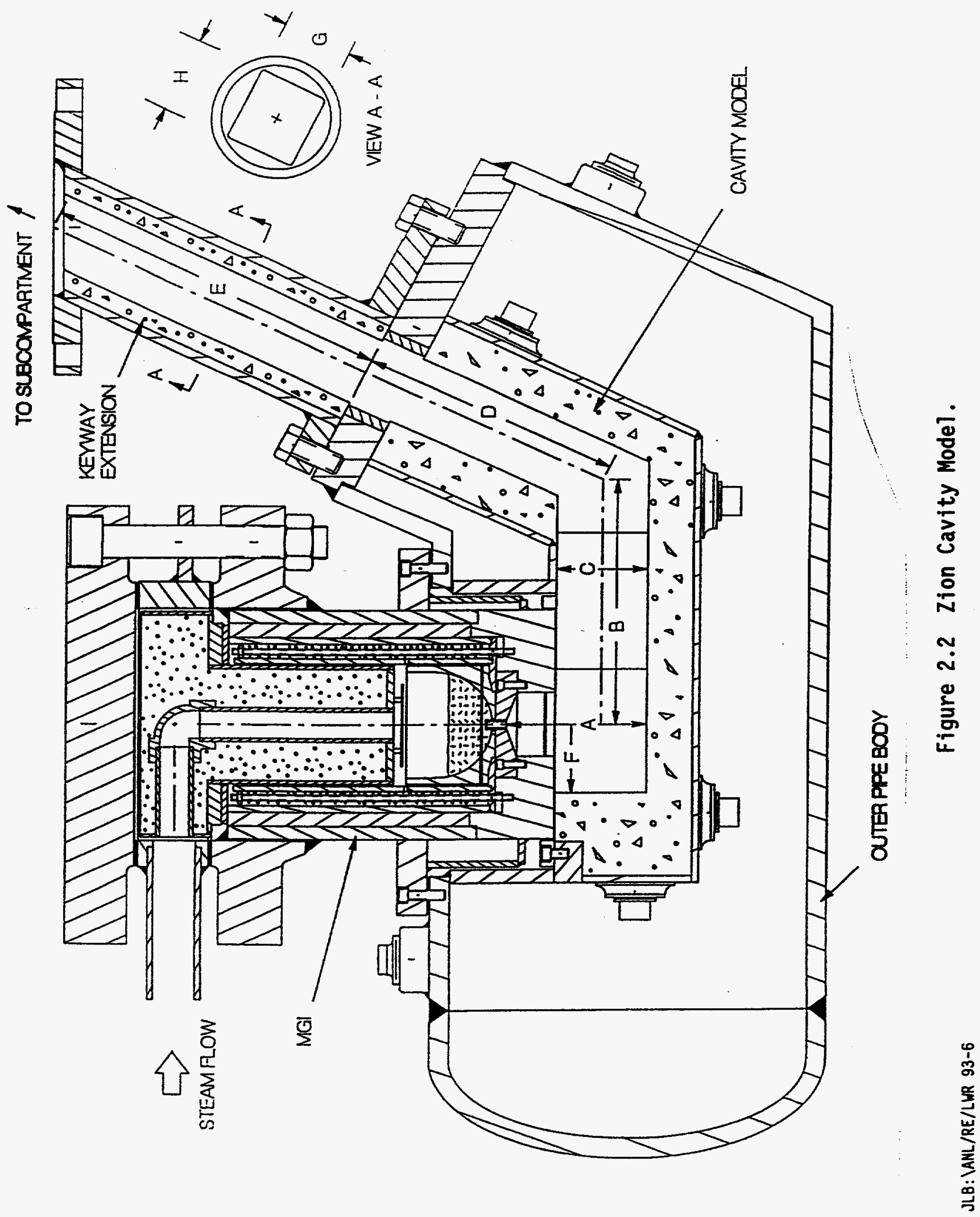



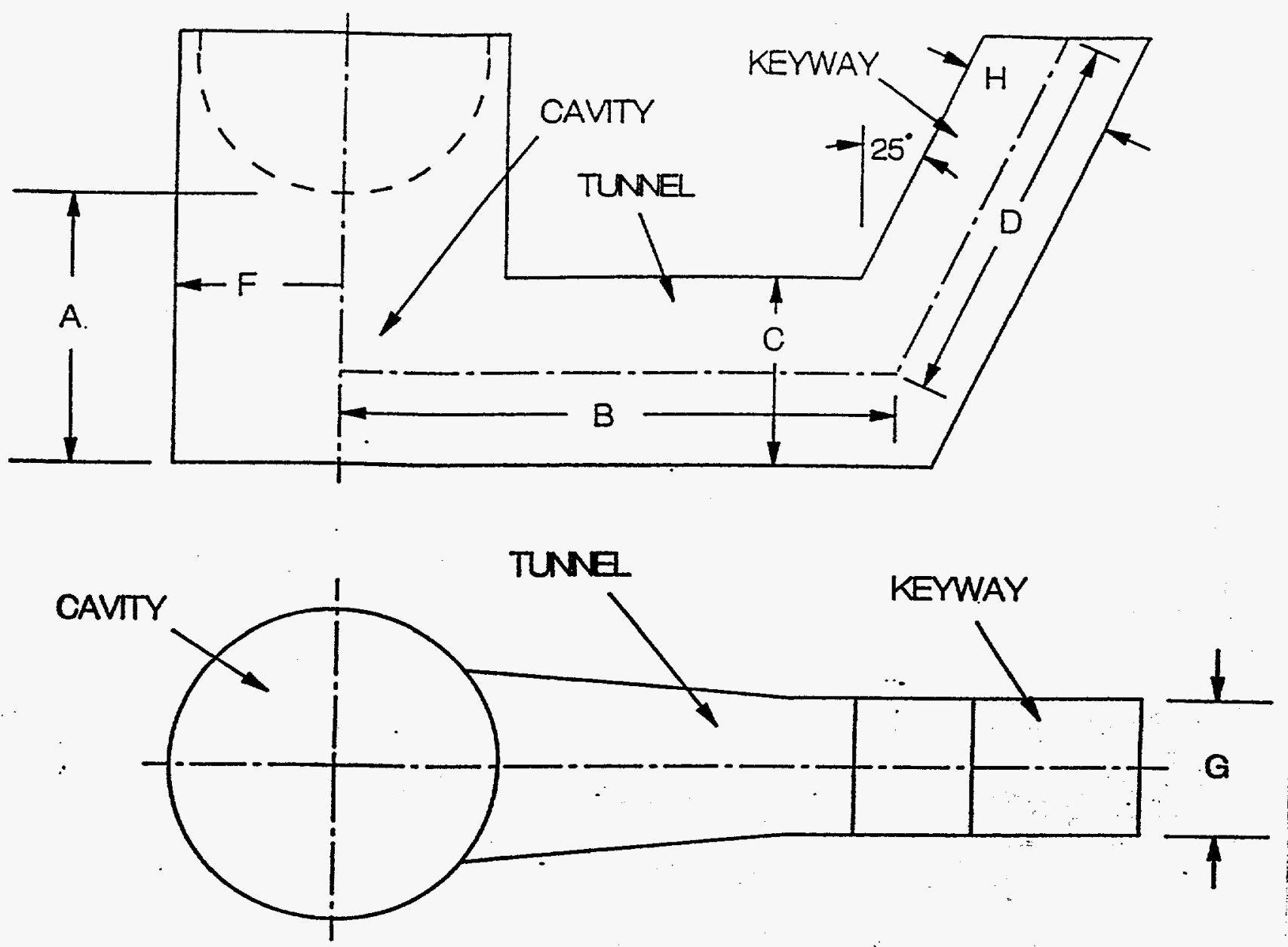

\begin{tabular}{|c|c|c|c|}
\hline Letter & Comment & $\begin{array}{c}\text { Zion } \\
\text { Full } \\
\text { Size, } \mathrm{m}\end{array}$ & $\begin{array}{c}\text { ANL } \\
2.55 \% \\
\mathrm{~m}\end{array}$ \\
\hline A & Orifice to Floor & 4.50 & 11.48 \\
\hline B & Tunnel Length & 8.81 & 22.47 \\
\hline C & Tunnel Height & 3.13 & 7.98 \\
\hline D & Keyway Length & 6.19 & 15.79 \\
\hline E & Keyway Extension & - & 31.0 \\
\hline F & Cavity Radius & 2.60 & 6.63 \\
\hline G & Keyway x-section & 2.29 & .5 .84 \\
\hline H & n & 2.39 & 6.10 \\
\hline
\end{tabular}

Figure 2.3 Internal Cavity Surface Dimensions. 
been modified to contain smaller amounts of thermite as required by the scaling analysis. The melt generator is shown in detail in Figure 2.4. The melt generator also includes a baffle plate in order to diffuse the steam jet entering from the accumulator. Shown in this drawing is the trace heaters on the internal $2.54 \mathrm{~cm}$ pipe. The heaters are encased in the magnesia.

The model of the Zion subcompartment is shown schematically in Figures 2.5 and 2.6. The model is a scaled down version of the model used in the SNL test. Prominent features which are modeled include the seal table room, refueling canal, biological shield wall, reactor coolant pumps, steam generators, floor grating and operating deck floor. The walls and floors are constructed from concrete and mortar. The structure has been painted with epoxy paint. The model was built up from the lower flange of the expansion vessel. The perimeter of the model is defined by a circular concrete wall which simulates the crane wall in the $\mathrm{plant.} \mathrm{The} \mathrm{walls} \mathrm{and} \mathrm{floors} \mathrm{are} \mathrm{held} \mathrm{together} \mathrm{by} 1 / 4$ " threaded rods. Seals are made at various joints with high temperature RTV silicon rubber.

\section{Instrumentation}

Table 2.1 details the type and location of instrumentation that was recorded during the test. The locations for the instrumentation in the subcompartment model is shown schematically in Figure 2.6.

\section{Pressure Measurements}

A11 pressure measurements were taken with strain gauge type transducers. The transducers were calibrated in the Engineering Development Laboratories calibration laboratory. The pressure measurements that are recorded during the test are listed below.
a) Accumulator Pressure History
b) Melt Generator Pressure History
c) Cavity Pressure History
d) Expansion Vessel Pressure

\section{Temperature Measurements}

a. Subcompartment and Expansion Vessel Temperatures

Temperature measurements were made with type $K$ thermocouples at various locations. The thermocouples in the subcompartment model had bare junctions. This allows for the fastest response to the high velocity hot gasses 


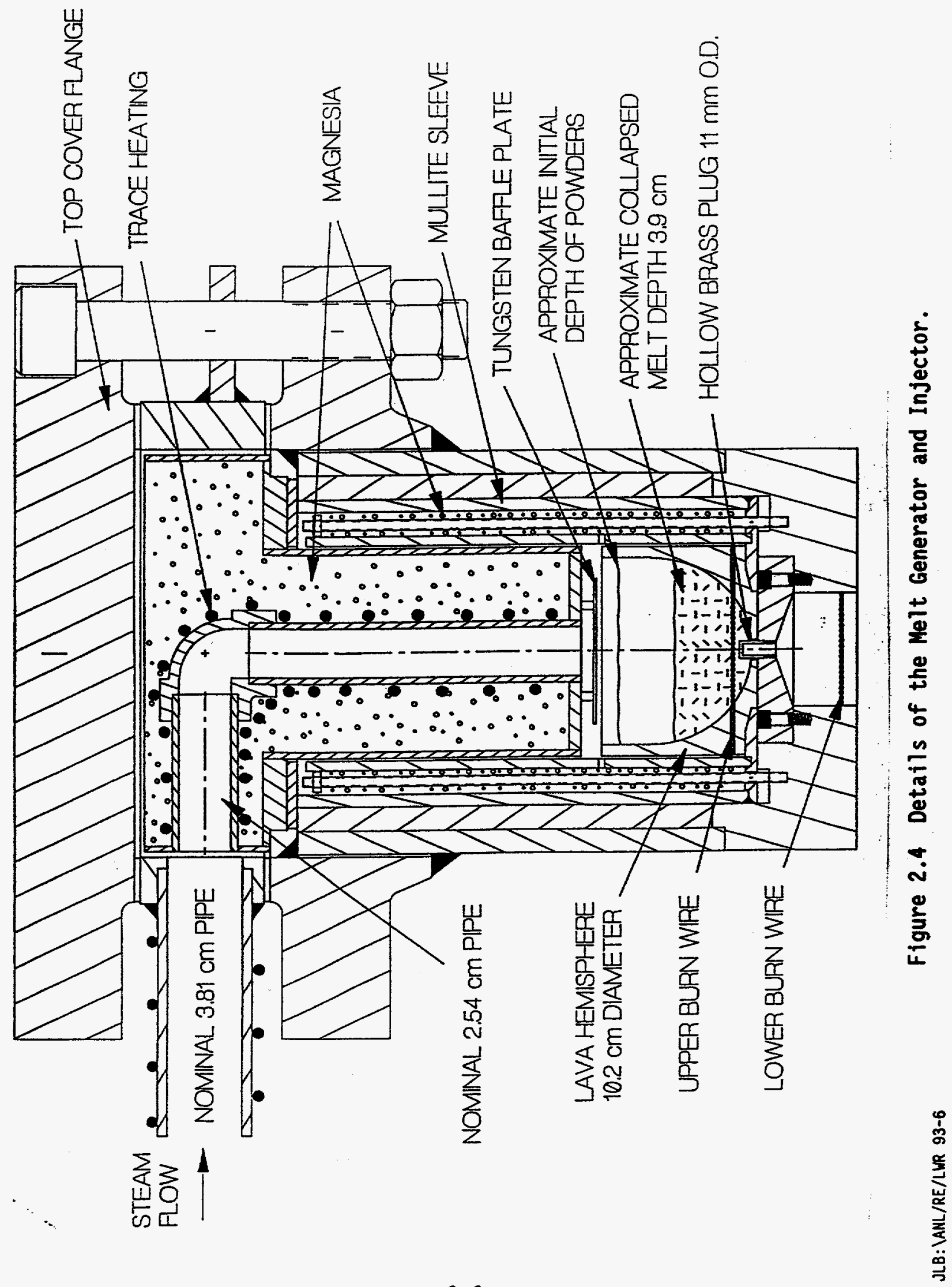




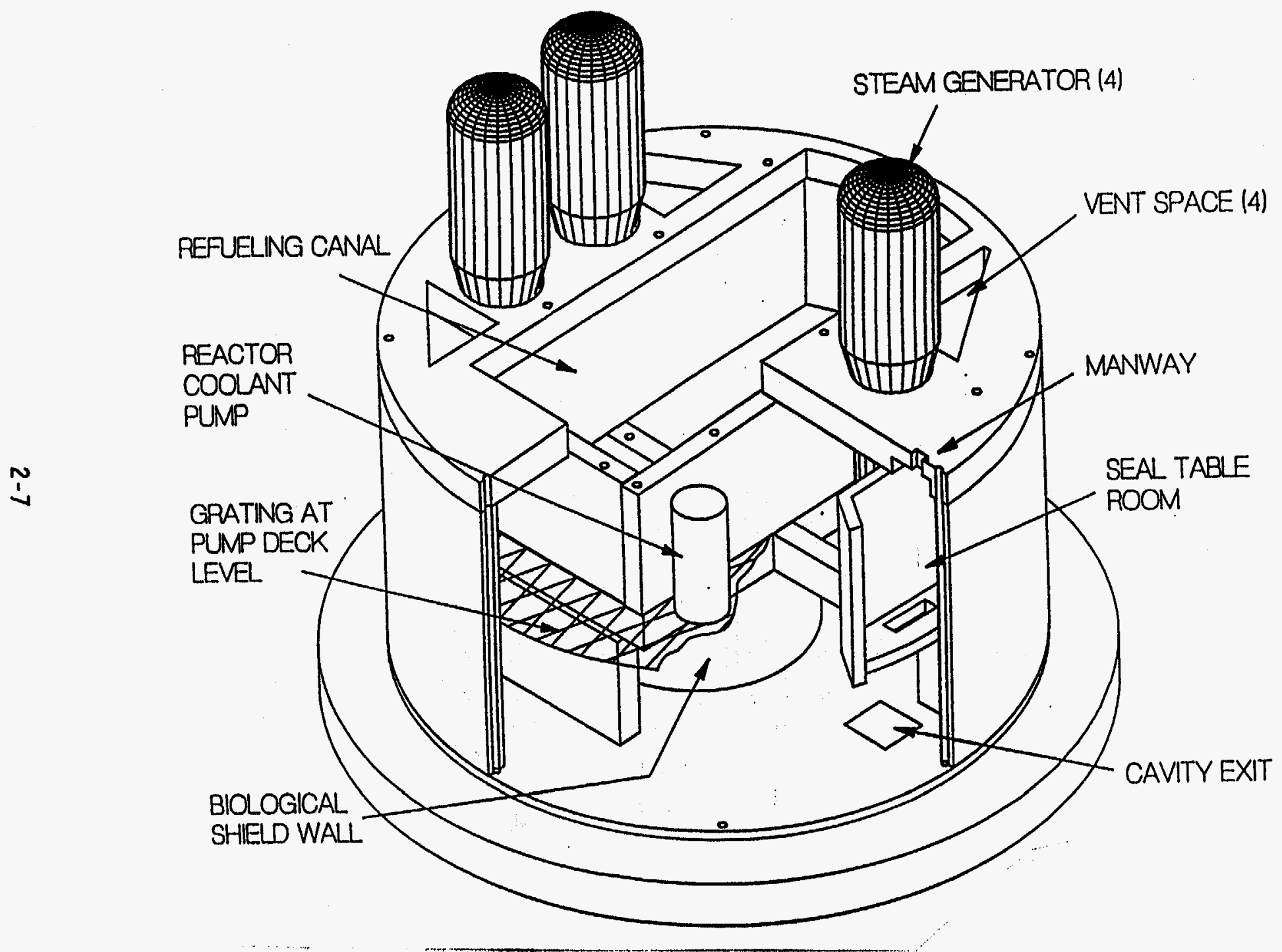




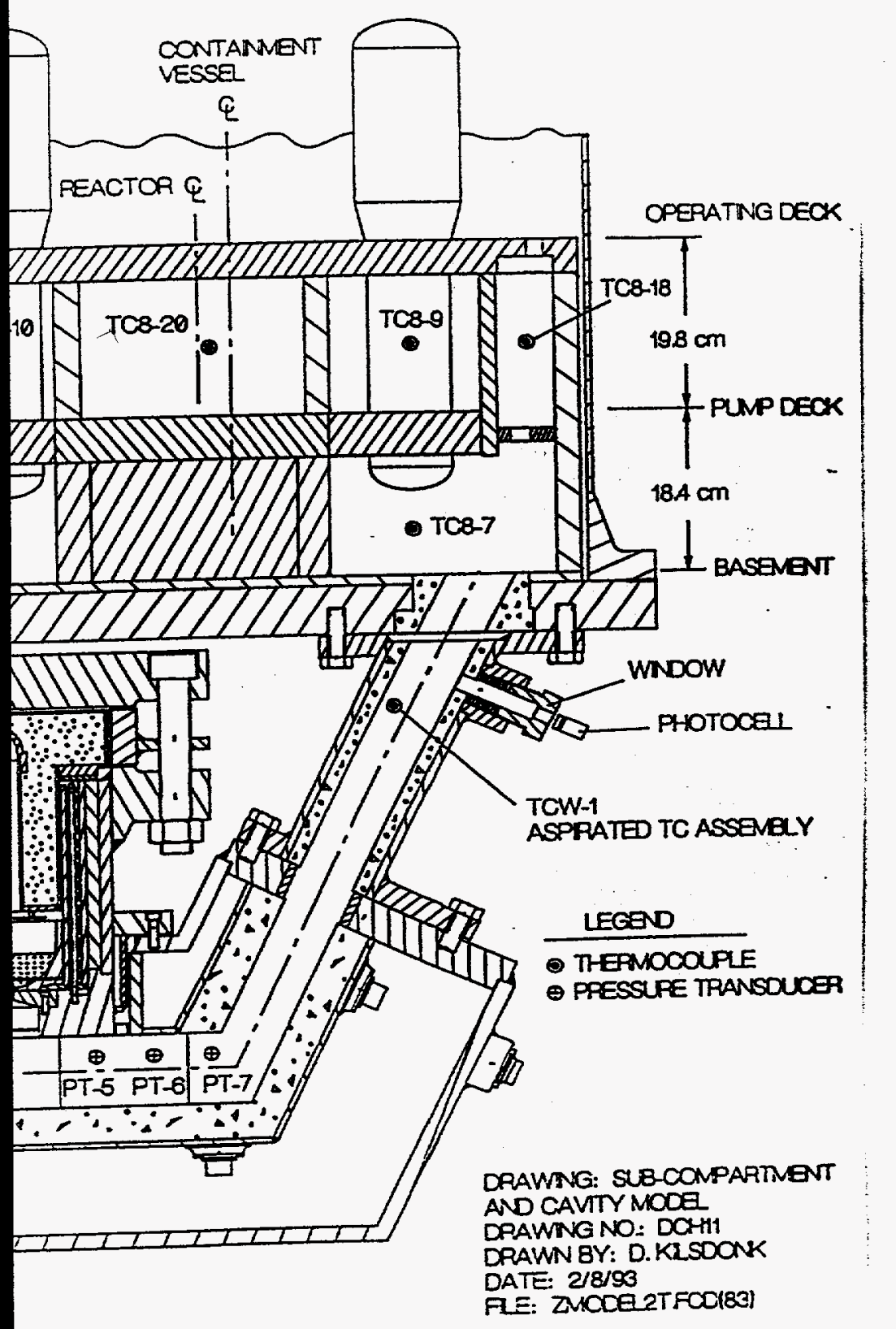

Subcompartment Model Showing Instrument Locations. 
Table 2.1 Instrumentation

\begin{tabular}{|c|c|c|c|c|}
\hline $\begin{array}{c}\text { Channel } \\
\text { No. }\end{array}$ & ID & Type $^{(1)}$ & Range & Location/Purpose \\
\hline 1 & IGN/LBW & Current/Continuity & $0-50 \mathrm{mV}$ & Ignition signal and start of HPME \\
\hline 2 & TC8-16 & Thermocouple & $0-485^{\circ} \mathrm{C}$ & Accumulator Gas Temperature \\
\hline 3 & TC8-17 & " & " & " " \\
\hline 4 & PTS-1 & Pressure Transducer & $0-1500$ psig & Accumulator Pressure \\
\hline 5 & PTS-2 & " & " & " \\
\hline 6 & UBW & Continuity & $0-1.5 \mathrm{~V}$ & Signal to Open Steam Valve \\
\hline 7 & PTS-3 & Pressure Transducer & $0-1500$ psig & MGI Pressure \\
\hline 8 & PTS-4 & " " & " & \\
\hline 9 & PTS-5 & " & $0-100$ psig & Cavity Pressure \\
\hline 10 & PTS-6 & $"$ & $0-500$ psig & " " \\
\hline 11 & PTS-7 & " & $0-1000$ psig & ( \\
\hline 12 & $\mathrm{PC}$ & Photoce11 & $0-1 \mathrm{~V}$ & Cavity Window/Measure Melt Ejection \\
\hline 13 & TC8-18 & Thermocouple & $0-1233^{\circ} \mathrm{C}$ & Seal Table Room Gas Temperature \\
\hline 14 & MS & Microswitch & $0-6 V$ & Valve Open Signal \\
\hline 15 & PTS-8 & Pressure Transducers & $0-125$ psia & EV Pressure \\
\hline 16 & PTS-9 & " & " & " " \\
\hline 17 & TC8-7 & Thermocouple & $0-1233^{\circ} \mathrm{C}$ & Subcompartment Gas Temperature \\
\hline 18 & TC8-8 & " & $n$ & $\begin{array}{lll}" & " & " 1\end{array}$ \\
\hline 19 & TC8-9 & $\overline{1}$ & $"$ & $"$ \\
\hline 20 & TC8-10 & " & " & " \\
\hline 21 & PTS-10 & Pressure Transducer & $0-100$ psig & EV Pressure \\
\hline 22 & PTS-11 & Pressure Transducer & $0-100$ psig & EV Pressure \\
\hline
\end{tabular}


Table 2.1 Instrumentation (Cont'd.)

\begin{tabular}{|c|c|c|c|c|}
\hline $\begin{array}{c}\text { Channel } \\
\text { No. }\end{array}$ & ID & Type ${ }^{(1)}$ & Range & Location/Purpose \\
\hline 23 & PTS-12 & $"$ & " & $"$ \\
\hline 24 & TC8-20 & Thermocouple & $0-485^{\circ} \mathrm{C}$ & Refueling Canal Temperature \\
\hline 25 & TC12-1 & " & $"$ & EV Temperature $\mathrm{H}=0.79 \mathrm{~m}$ \\
\hline 26 & TC12-2 & " & $"$ & " $\quad H=1.22 \mathrm{~m}$ \\
\hline 27 & TC12-3 & $"$ & " & " $\quad H=1.63 \mathrm{~m}$ \\
\hline 28 & $\mathrm{TC} 12-4$ & " & $"$ & " $\quad \mathrm{H}=1.83 \mathrm{~m}$ \\
\hline 29 & PTS-13 & Pressure Transducer & $0-100$ psig & Aspirated TC Assembly Pressure \\
\hline 30 & TCW-1 & Thermocouple W-Re, Bare & $0-2300^{\circ} \mathrm{C}$ & Cavity Gas Temperature \\
\hline 31 & TC12-5 & Thermocouple & $0-485^{\circ} \mathrm{C}$ & EV Temperature $H=2.13 \mathrm{~m}$ \\
\hline 32 & TC12-6 & $"$ & " & $H=2.59 \mathrm{~m}$ \\
\hline
\end{tabular}

(1) All thermocouples are bare junction Type $K$ unless otherwise noted.

$H=$ Height above operating deck. 
entering the subcompartment model. The thermocouples located in the expansion vessel were also bare junction. In addition, many thermocouples were located on the vessel and cavity sections and flanges for temperature monitoring during heatup.

\section{b. Cavity Gas Temperature}

Cavity gas temperature were measured by an aspirated thermocouple assembly which is depicted in Figure 2.7. The assembly consists of a barejunction thermocouple, Type $C$, shielded by $1 / 4$ " stainless steel tube. The tube has a slot cut in the end to draw gas through and over the bead. The flow area through the slot equals the cross sectional flow area of the tube. The junction is set back away from the slots. The tube is inserted into the cavity through a hole in the wall near the cavity exit and in the same plane as the quartz window. The end of the tube extends one inch past the wall into the cavity. The slot is positioned away from the direction of the flow. The opposite end of the tube is secured on the outside of the cavity model by a swagelock fitting. The end of the tube is connected to a solenoid valve which vents the assembly to a gas bottle. The solenoid valve is opened from 0 to 1.0 seconds after the start of the HPME.

\section{Melt Ejection Indication}

The start of the high pressure melt ejection is signalled by a twisted pair of varnished copper wires located just below the brass melt plug. When melt is ejected it contacts the wires, vaporizing the varnish and making an electrical connection between the two wires. The shorting of the two wires produces a 60 $\mathrm{Hz}$ signal which is recorded on the data acquisition system. This signal also actuates the automatic gas sampling system.

\section{Data Acquisition}

All of the instrumentation shown in Table 2.1 is recorded at $40 \mathrm{kHz}$ on a Metrum VHS recorder. For redundancy a portion of the channels were also recorded on a fibre-optics oscillograph recorder. The data was retrieved and reduced from the VHS tape with a data acquisition system on a personal computer. The data was sample and plotted at progressively higher rates until all transients in the data were resolved. 


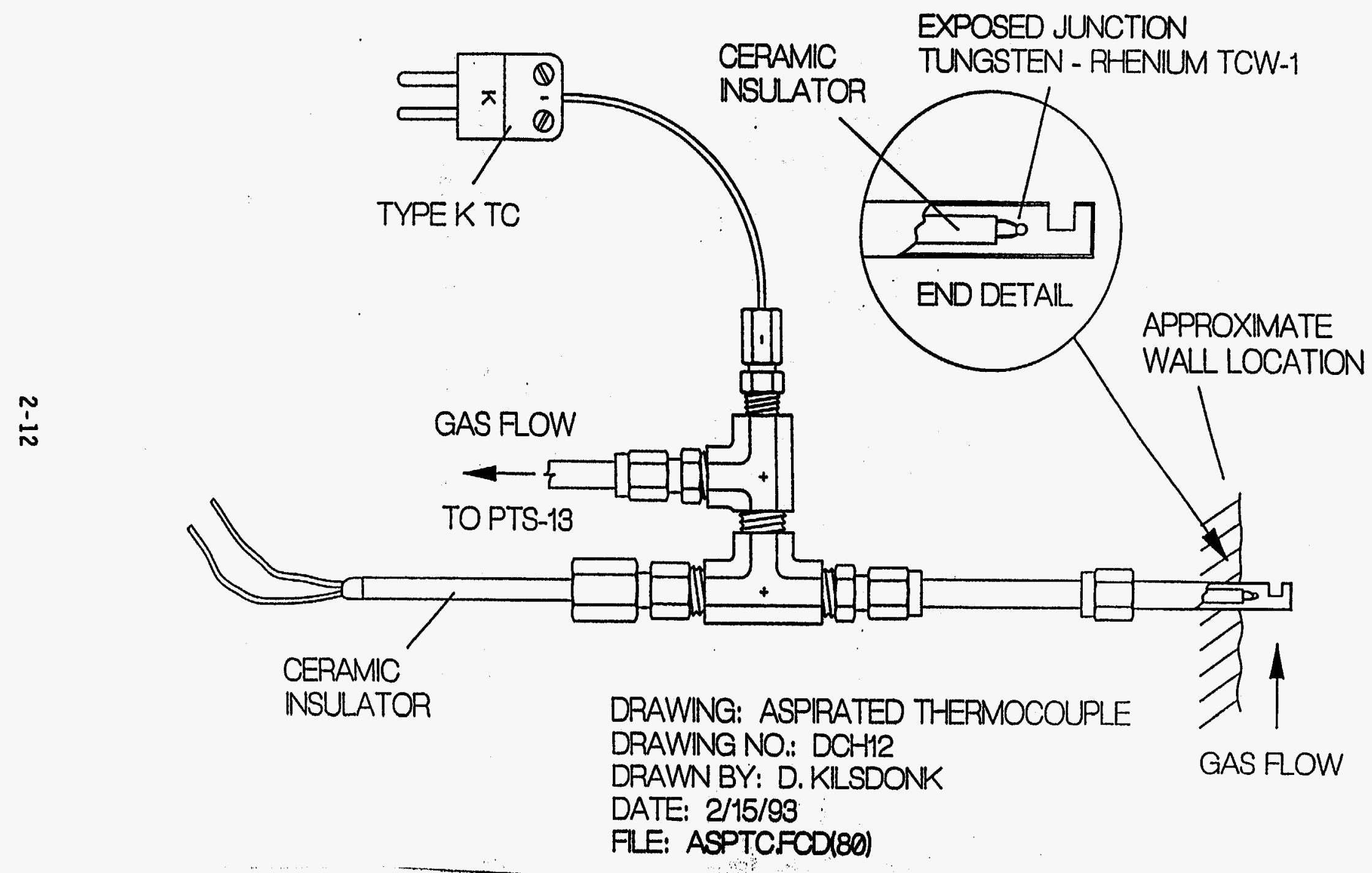


5. Gas Composition Measurements

Gas composition measurements were made by use of gas grab sample bottles. The timing of the sample measurements referenced to the start of the high pressure melt ejection are shown in Table 2.2. Bottles 1-3 and 11-18 are made automatically. All other samples are taken manually. All sample bottles are evacuated prior to the test.

Table 2.2 Gas Bottle Locations and Timing

\begin{tabular}{|c|c|c|}
\hline Bottle & Location & Timing \\
\hline 1 & Cavity/Aspirated TC & 0.0 to 1.0 secs \\
\hline 2 & Cavity & 15.0 to 16.0 secs \\
\hline 3 & Cavity & 60.0 to 61.0 secs \\
\hline 4 & Upper Dome & Background \\
\hline 5 & Upper Dome & Background \\
\hline 6 & Upper Dome & At 1.0 min. manually \\
\hline 7 & Upper Dome & At 1.0 min. manual1y \\
\hline 8 & Upper Dome & At 7.5 min. manually \\
\hline 9 & Upper Dome & At 7.5 min. manually \\
\hline 10 & Upper Dome & At 7.5 min. manually \\
\hline 11 & Upper Dome & 30.0 to 31.0 secs \\
\hline 12 & Upper Dome & 30.0 to 31.0 secs \\
\hline 13 & Upper Dome & 30.0 to 31.0 secs \\
\hline 14 & Upper Dome & 5.0 to 6.0 secs \\
\hline 15 & Upper Dome & 15.0 to 16.0 secs \\
\hline 16 & Upper Dome & 30.0 to 31.0 secs \\
\hline 17 & Upper Dome & 60.0 to 61.0 secs \\
\hline 18 & Upper Dome & 450.0 to 451.0 secs \\
\hline
\end{tabular}

\section{Debris Recovery}

The disposition of the thermite melt was measured after the test. The recovery was typically made by vacuuming the debris from each specific location of interest. The debris is maintained in sealed plastic bags. Particle sizing, when possible, was carried out with a sonic sifter. 
D. Test Procedures

1. Pretest Operations

The subcompartment model is assembled and instrumented on top of the lower head of the EV. The EV is assembled and instrumented. The top cap is bolted into $\mathrm{place}$ on the cavity model and the melt generator is readied to load the thermite. The thermite is mixed in a glove box and then placed into a sealed container. The MGI is purged with argon and the thermite is loaded. The ignitor assembly is put into place near the top of the thermite charge. The thermite is tamped down. The MGI is closed up and an argon purge is maintained. The cavity model is then rolled, jacked and bolted into place under the EV. The accumulator is put into place and all plumbing connections are made. The final pretest operation is to check that instrumentation is completed and functioning properly.

\section{Test Operations}

Test operations are begun by preheating the apparatus to the correct initial temperatures. The initial containment atmosphere composition is set. If called for by the test, water is added to the cavity. The steam generator is brought to the test specified pressure. At this point the doors on the cell are closed and the ignitor assembly is connected to a power supply. The accumulator is pressurized with steam from the boiler to the test specification. The scrubber ventilation is started. The test is ready to begin the automatic sequence.

The test is begun by starting the data acquisition and then depressing a button which starts a timer. This applies power to the ignitor assembly which initiates the thermite reaction. The reaction proceeds downward until it hits a burn wire located above the melt plug. This actuates the opening of the steam valve. The time to fully open the valve is on the order of 100 milliseconds. At some time after the steam introduction the thermite reaction reaches the brass plug in the melt generator and fails the plug. This starts the high pressure melt ejection and is signalied by the burn wire under the plug. The burn wire signal starts a timer which actuates the automatic gas sample bottles. At specified times after the melt ejection gas samples are also taken manually.

\section{Posttest Operations}

The apparatus is carefully disassembled. During this time photographs were taken to document the debris disposition during the various disassembly JLB: LANL/RE/LWR 93-6 2-14 
stages. Gas sample bottles are isolated, sealed, and sent to the Analytical Chemistry Lab for analyses.

\section{E. Corium Characterization}

1. Prototype Core Melt Composition

The anticipated prototype core melt composition is assumed from the analysis of Levy (1991). Levy synthesized the predicted core melt progression of available code analyses for a station blackout accident at the Surry Nuclear Power Plant. An instrument tube penetration failure is assumed to start the high pressure melt ejection. For this scenario Levy estimated that a total of 44 metric tons of molten material would be available for ejection. The composition of the molten material is shown in Table 2.3. Following Pilch, Levy calculated that this scales to 54 MT for the Zion plant. In order to have a bound on the total amount of metallic zirconium the $11,130 \mathrm{~kg}$ of $\mathrm{U}-\mathrm{Zr}-0$ eutectic was broken down as follows. It is assumed that all of the uranium originated as $\mathrm{UO}_{2}$. This is subtracted from the eutectic, leaving $\mathrm{Zr}$ and some oxygen. It is assumed that the remaining oxygen had reacted with $\mathrm{Zr}$ to produce $\mathrm{ZrO}_{2}$. What remains is metallic $\mathrm{Zr}$. Thus, the eutectic is assumed to be made up of 46.5 mass\% $\mathrm{UO}_{2}, 40.2$ mass\% $\mathrm{ZrO}_{2}$, and 13.3 mass\% $\mathrm{Zr}$. The stainless steel is assumed to be composed of

Table 2.3 Synthesized Molten Melt Composition for an Instrument Tube Penetration Failure at Surry from Levy (1991)

\begin{tabular}{|l|c|}
\hline \multicolumn{1}{|c|}{ Composition } & Mass (Kg) \\
\hline \hline Steel & 8,970 \\
\hline $\mathrm{Zr}$ & 4,790 \\
\hline $\mathrm{UO}_{2}$ & 18,930 \\
\hline $\mathrm{ZrO}_{2}$ & 0 \\
\hline $\mathrm{U}-\mathrm{Zr}-0(41 / 43-16)$ & 11,130 \\
\hline Total & 43,820 \\
\hline
\end{tabular}

74 mass\% $\mathrm{Fe}, 18$ mass\% $\mathrm{Cr}$ and 8 mass\% $\mathrm{Ni}$. The assumed composition of the prototype core melt, broken down into its fundamental oxide and metallic constituents, is shown in Table 2.4 under the heading SASM. 
Table 2.4 Summary of Core Melt and Simulant Compositions (mass fraction).

\begin{tabular}{|l|l|c|c|}
\hline & SASM & $\mathrm{Fe} / \mathrm{Al}_{2} \mathrm{O}_{3} \mathrm{~W} / \mathrm{Cr}$ & Corium \\
\hline $\mathrm{UO}_{2}$ & 0.550 & 0.0 & 0.578 \\
\hline $\mathrm{Zr}$ & 0.143 & 0.0 & 0.137 \\
\hline $\mathrm{ZrO}_{2}$ & 0.102 & 0.0 & 0.105 \\
\hline $\mathrm{Fe}$ & 0.152 & 0.505 & 0.143 \\
\hline $\mathrm{Cr}$ & 0.0369 & 0.108 & 0.0371 \\
\hline $\mathrm{Ni}$ & 0.0164 & 0.0 & 0.0 \\
\hline $\mathrm{Al}_{2} \mathrm{O}_{3}$ & 0.0 & 0.373 & 0.0 \\
\hline $\mathrm{Al}$ & 0.0 & 0.0139 & 0.0 \\
\hline
\end{tabular}

\section{Experiment Simulant}

The best available method for generating prototypic melts for $\mathrm{DCH}$ experiments is through thermite type reactions. Several options were considered for the potential experiment melt composition. Development testing was carried out in order to verify the viability of a possible composition. A development test consisted of mixing powders of the proposed compositions in the a crucible and then igniting the mixture with a nichrome wire. A viable candidate was found if the reaction was self-sustaining, the mixture became fully molten and exhibited good flow properties. Temperature of the melt was measured in two ways. First there were tantalum sheathed type $C$ thermocouples located in the MGI. Secondly, two pyrometers were focused on the melt stream exiting the injector.

From the development testing a thermite type reaction which produced an excellent prototypic melt was identified. The reaction is given by

$$
15 \mathrm{U}+6 \mathrm{Zr}+9 \mathrm{Fe}_{2} \mathrm{O}_{3}+5 \mathrm{CrO}_{3}+10.5 \mathrm{Zr}_{1} 15 \mathrm{UO}_{2}+6 \mathrm{ZrO}_{2}+18 \mathrm{Fe}+10.5 \mathrm{Zr}+1.87 \frac{\mathrm{MJ}}{\mathrm{Kg}}
$$

Two tests were run with the same composition to check for reproducible behavior. The approximate composition of the experiment melt is shown in Table 2.4 under the heading Corium. Close approximation of the prototype is noted. The simulant used in the IET tests is given for comparison.

The temperature of the melt after complete reaction will depend upon several factors. An upper bound can be estimated by assuming that the reaction 
takes place adiabatically. The heats of formation of the reactants and products together with the enthalpy data yields a temperature of 3280K (Baker, 1993). In practice this temperature will not be realized due to several limiting heat transfer and thermodynamic factors. The following two are the most important. First, the reaction crucible is not a true adiabatic container and there will be heat losses to the surrounding structure. Secondly, the temperature will be limited by the boiling points of the metal constituents. The boiling temperatures for $\mathrm{Cr}$ and $\mathrm{Fe}$ are $2945 \mathrm{~K}$ and $3080 \mathrm{~K}$, respectively. Thus, energy must go into vaporizing these constituents to rise to the adiabatic temperature.

Figure 2.8 shows the temperatures measured by the tantalum sheathed type C thermocouples located in the melt in the two development tests. The thermocouples measured peak temperatures in the range from 2600 to $2750 \mathrm{~K}$. Figure 2.9 shows the temperature measured by a pyrometer focused on the melt stream exiting the crucible. The data obtained by the pyrometer shows a considerable amount of noise. The source of this noise is the large amount of aerosol surrounding the melt stream, partially obscuring it and producing the unclean signal. The data was smoothed numerically and the smoothed data is also plotted on the figures. The smooth signals show temperature peaks at approximately $2800 \mathrm{~K}$. From this data it is concluded that the melt obtains a temperature in the range of 2600 to $2800 \mathrm{~K}$ with $2700 \mathrm{~K}$ being the recommended value.

The actual melt composition formed by the reaction will not match the right hand side of equation (2-1) or the composition given in Table 2.4. The following discussion is adapted from the work of Baker (1993). The melt will consist of two immiscible compositions, a metal and an oxide. The metal will consist of mostly zirconium with some uranium. In addition there is substantial solubility of oxygen in a zirconium-uranium liquid, metallic phase. If the materials reach an equilibrium, the oxide will be in the form $(U, \mathrm{Zr}) \mathrm{O}_{2-x^{\circ}}$. It is generally assumed that the steel, i.e, iron and chromium will be miscible with the zirconium melt. There are two significant effects of this type of equilibration. The first is to decrease the differences in density between the two phases. This was partially evidenced by examining the melt composition obtained in the development tests. Microscope examination revealed that the phases were intimately mixed, indicating that segregation of the phases did not occur before solidification. This is in contrast to the iron/alumina mixture which rapidly 


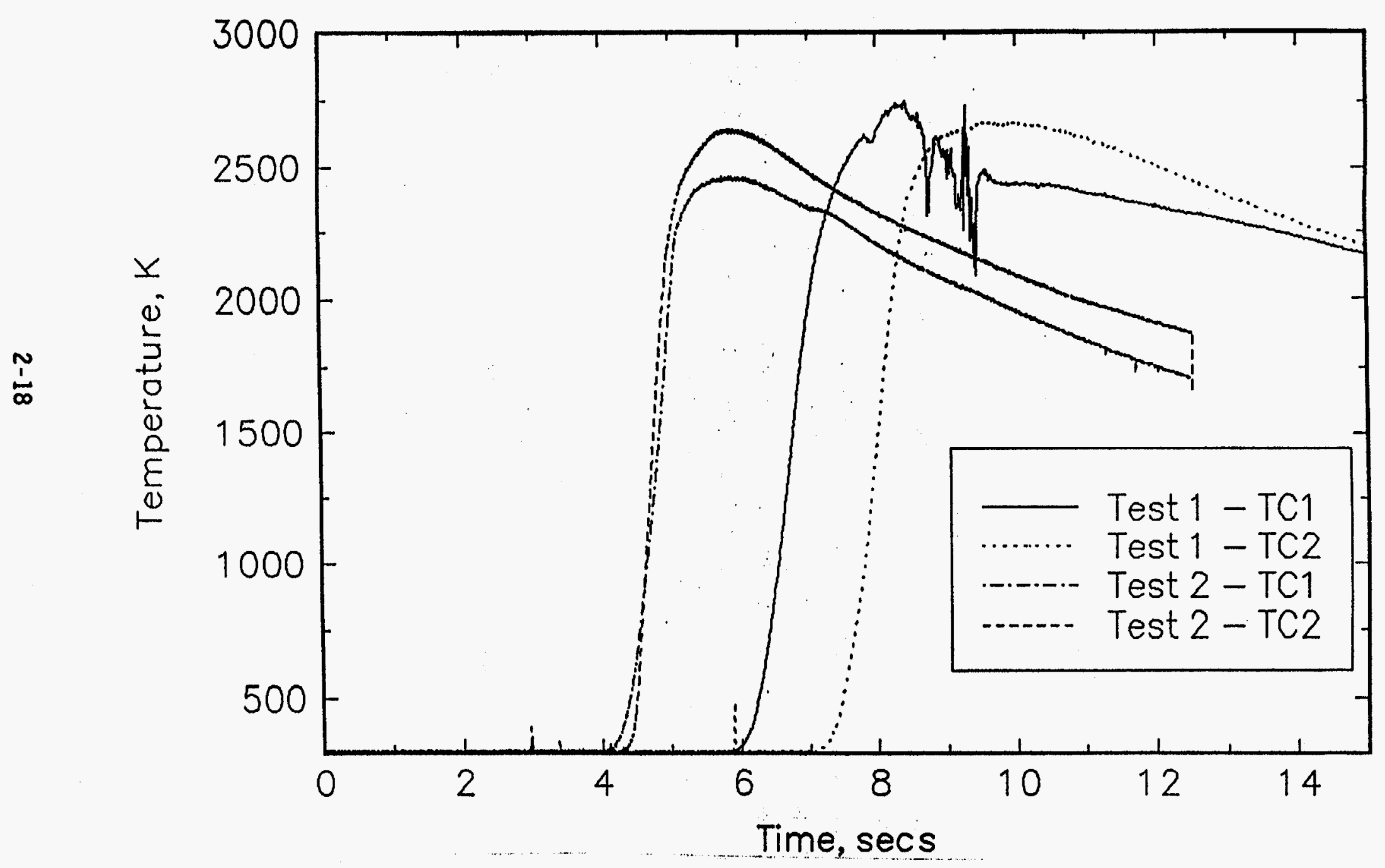




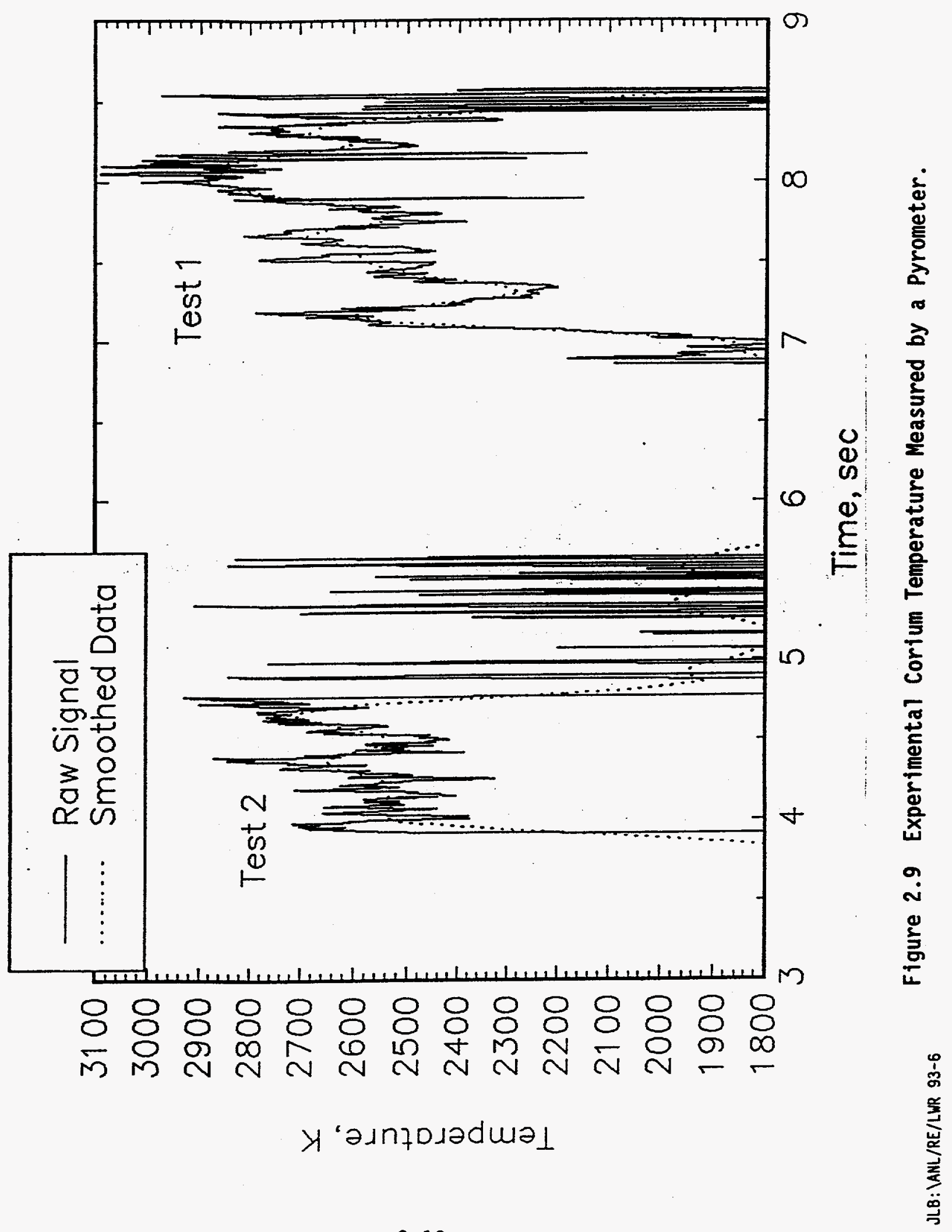


segregates due to the large density difference between the metal and oxide. It is also likely that difference in surface tension is decreased. A second effect of this equilibration is to leave the oxide as well as the metal deficient in oxygen. Therefore, the oxide could later react with the steam during the $\mathrm{DCH}$ process. The individual heats of reaction are not known well known.

The above discussion was given only to suggest the possible form of the melt. The determination of the exact composition would require a detailed phase and chemical characterization of the end product. However, this type of analysis would be difficult, due to the close mixing of the phases. The analysis would require careful separation of the phases, characterization by $X$-ray diffraction, followed by an elemental and oxygen content analysis. This detailed chemical analysis was not possible.

3. Scaling Considerations

It is clear that the melt developed here for the present DCH experiments is favorable to iron/alumina thermite for DCH tests due to its prototype properties. The most important of these differences will be elaborated on in this section. In addition the scaling criteria for selecting initial melt mass will be established. For purposes of making comparisons and establishing the scaling criteria, the composition of the melt will be assumed to be given by the right hand side of equation 2-1. This is equivalent to the mass fraction given in Table 2.4

Figure 2.10 plots the prototype and simulant melt enthalpies as a function of temperature. It is clear that the iron/alumina melt contains significantly more thermal energy. At the iron/alumina melt temperature, $2500 \mathrm{~K}$, the enthalpy is $2.65 \mathrm{MJ} / \mathrm{kg}$. At this temperature there is approximately 200, 700 and 370 degrees of superheat in the alumina, iron and chromium respectively. The superheat in the iron is important because it makes up $50.5 \%$ of the mass of the melt. At the corium simulant temperature of $2700 \mathrm{~K}$ the enthalpy is $1.2 \mathrm{MJ} / \mathrm{kg}$. The amount of superheat is difficult to determine because of the uncertainties in the melt form. However, the amount of superheat in the oxide is expected to be sma11. The oxide phase accounts for approximately $65 \%$ of the corium mass. Because of this freezing effects can provide a significant 1 imitation to melt entrainment and ultimately the transfer of heat from the melt to the containment atmosphere. 


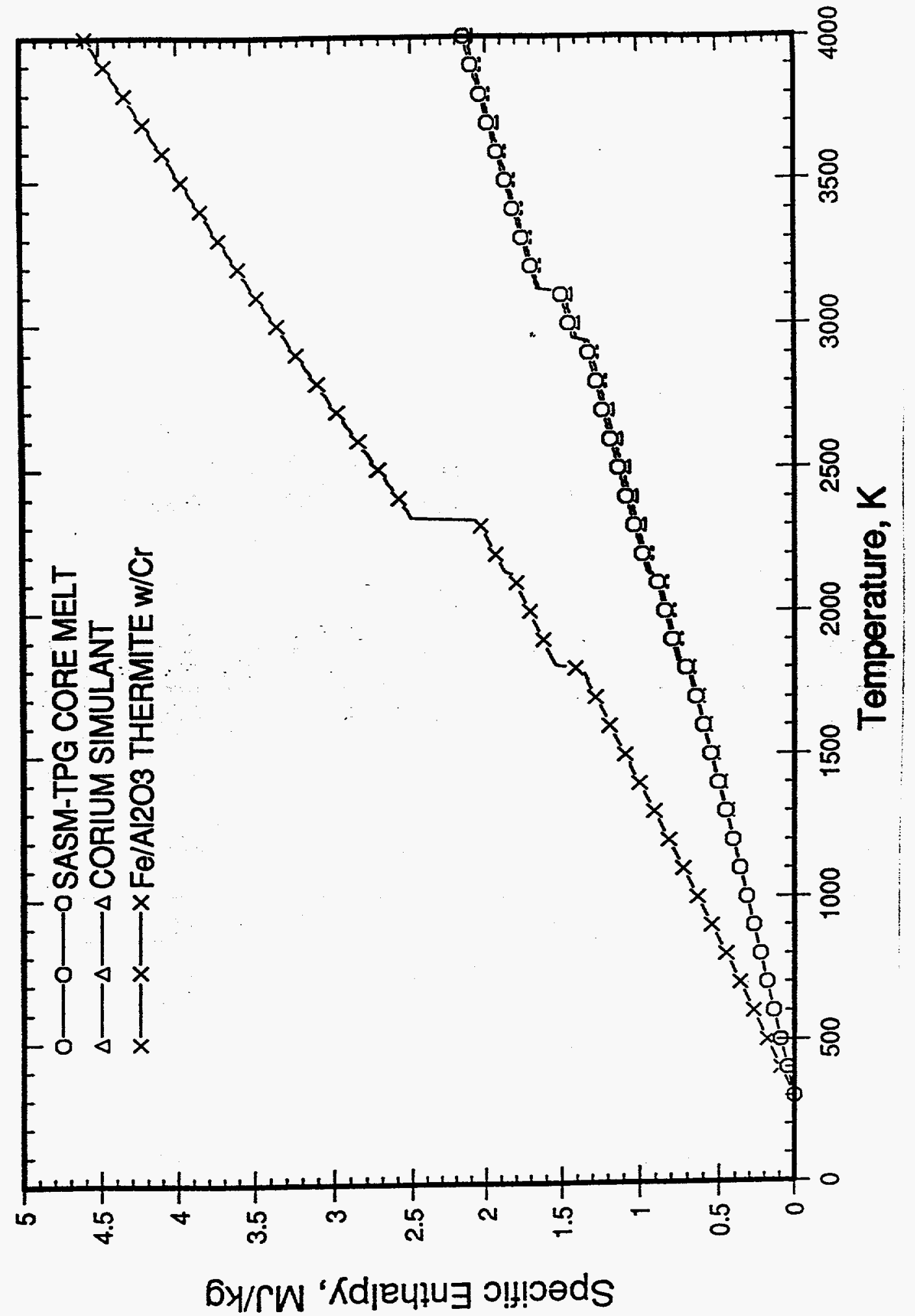


A second important difference between the simulants is the oxidation potential of the two. A significant fraction of the iron/alumina thermite is made up of metal, however, this is predominantly iron. The iron is a weak oxidizer when compared to zirconium, chromium and aluminum. By weak oxidizer it is meant that the Gibbs free energy for reaction is relatively low. Thus, the other metals will react preferentially and the heat of reaction is small. This was the motivation for adding chromium to the iron/alumina thermite mixture. In contrast, the corium simulant contains significantly less metal, by mass fraction, compared to the iron/alumina simulant. However, the fraction which is a strong oxidizer is larger. These differences can be noted in Table 2.5 below. From the data it is noted that the total available oxidation energy is the same for the two melts. However, for the case of the corium, a larger percentage, $\mathbf{8 8 . 0 \%}$, will come from exothermic metals as compared to $\mathbf{5 6 . 4 \%}$ for iron/alumina. In addition the potential exists for producing over twice as many moles of hydrogen with the iron/alumina thermite. However, if only the exothermic metals are considered, the corium could potentially produce $18.0 \%$ more hydrogen than the iron/alumina thermite.

Table 2.5 0xidation Characteristics of Melt Simulants with Steam

\begin{tabular}{||c|c|c|c|c|}
\hline Contributor & $\begin{array}{c}\text { g-moles of } \mathrm{H}_{2} \\
\text { Produced per } \\
\text { Mass 0xidized } \\
\mathrm{Fe} / \mathrm{Al}_{2} \mathrm{O}_{3} \text { W/Cr }\end{array}$ & $\begin{array}{c}\text { g-moles of } \mathrm{H}_{2} \\
\text { Produced per } \\
\text { Mass 0xidized } \\
\text { Corium }\end{array}$ & $\begin{array}{c}\text { Energy } \\
\text { Released per } \\
\text { Mass oxidized } \\
\mathrm{Fe} / \mathrm{Al}_{2} \mathrm{O}_{3} \text { W/Cr } \\
\text { MJ/kg }\end{array}$ & $\begin{array}{c}\text { Energy } \\
\text { Released per } \\
\text { Mass 0xidized } \\
\text { Corium } \\
\text { MJ/kg }\end{array}$ \\
\hline $\mathrm{Zr}$ & 0 & 3.00 & 0.0 & 0.88 \\
\hline $\mathrm{Cr}$ & 3.11 & 1.07 & 0.45 & 0.16 \\
\hline $\mathrm{Al}$ & 0.39 & 0.0 & 0.21 & 0.0 \\
\hline $\begin{array}{c}\text { Total of } \\
\text { Exothermics }\end{array}$ & 3.50 & 4.07 & 0.66 & 1.04 \\
\hline $\mathrm{Fe}$ & 12.0 & 3.40 & 0.51 & 0.14 \\
\hline \hline Total & 15.5 & 7.47 & 1.17 & 1.18 \\
\hline
\end{tabular}

Energy to volume scaling has been used to specify the initial melt mass in the Counterpart Integral Effects Test (Pilch (1991)). The objective is to match the ratio of the total possible energy input to the containment volume in the 
experiment with the reactor case. This is equivalent to matching the maximum theoretical containment pressure increase, $\Delta P_{\max }$, normalized by the initial containment pressure, $P_{c, o}$, at reactor and experiment scale. Following the developments given in Pilch (1991) the dimensionless ratio is given by

$$
\frac{\Delta P_{\max }}{P_{c, 0}}=\frac{\gamma-1}{1+\left(M_{d}\right)} \frac{\Delta E\left(M_{d}\right)}{P_{c, 0} V_{R C B}} .
$$

where

$$
\begin{aligned}
& \boldsymbol{\gamma}=\text { heat capacity ratio for containment gasses, } \\
& \psi=\frac{M_{d} C_{d}}{N_{g} C_{v}}=\begin{array}{c}
\text { ratio of debris heat capacity to the total heat capacity } \\
\text { of the containment gasses, }
\end{array} \\
& P_{c, 0} \quad=\text { initial pressure in the containment, } \\
& V_{\text {RCB }}=\text { volume of reactor containment, } \\
& M_{d} \quad=\text { mass of debris. }
\end{aligned}
$$

The total energy available for direct containment heating, $\Delta E$, is a function of the debris mass and is given by the contribution of various sources and sinks as

$$
\Delta E=\Delta E_{B}+\Delta E_{T}+\Delta E_{\text {ox }}+\Delta E_{H_{2}}-\Delta E_{\text {vap }}-\Delta E_{\text {gas }} \text {. }
$$

Here the sources and sink terms are defined as follows:
$\Delta E_{B} \quad=$ source due to RCS blowdown,
$\Delta E_{T} \quad=$ source due to thermal energy of the debris,
$\Delta E_{o x}=$ source due to oxidation of metallic debris by steam,
$\Delta E_{\mathrm{H}_{2}}=$ source due to combustion of $\mathrm{H}_{2}$,
$\Delta E_{\text {vap }}=$ net effect of vaporization of water by melt,
$\Delta E_{g s}=$ sink due to gas/structure heat transfer.

Pilch and Allen (1991) have given estimates of these source and sink terms.

The energy to volume ratio estimate given by (2-2) has been calculated at the reactor scale in Figure 2-11 and for the thermite generated core melt simulants in Figures $2-12$ and $2-13$ as a function of melt mass. The total and the four major contributors (RCS blowdown, thermal energy in the melt, metal oxidation by steam and hydrogen combustion) are shown. The initial conditions 


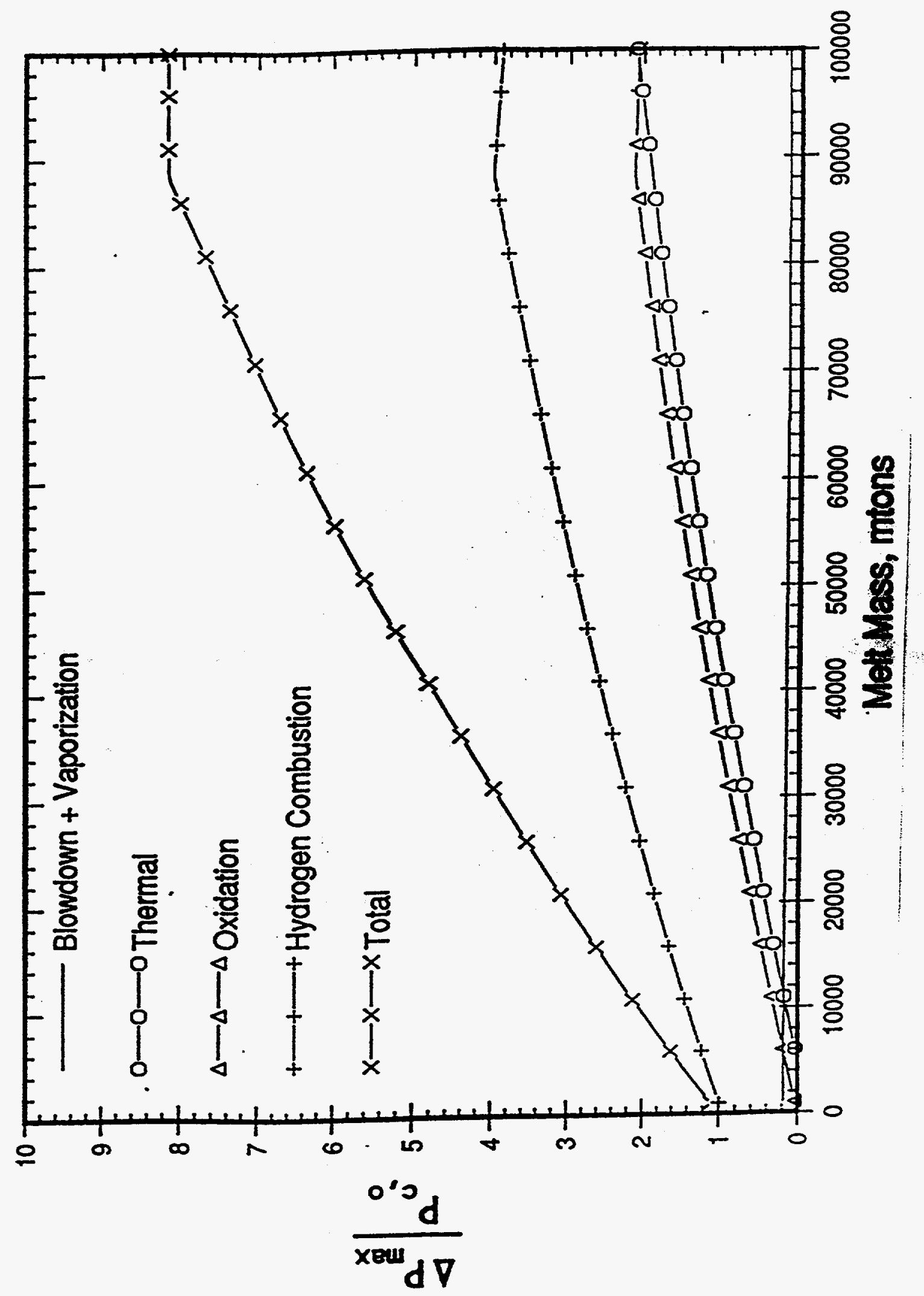


that were assumed to make these calculations are given in Table 2.6 below. The experiment values are given in full scale and at experiment scale. Note that the containment volume is over scaled by $18.3 \%$. The containment atmospheres were assumed to be the same for the reactor and experiment. The number of moles of cavity water were taken from the scaling study of Pilch for the reactor. The following assumptions were made in these calculations:

1) The water in the cavity was assumed to be completely vaporized by the melt which presents a net sink to the containment load.

2) The gas/structure heat transfer sink was ignored.

3) A11 of the melt mass contributed as fragmented debris.

4) All of the melt was oxidized in the steam to the extent that steam is available.

5) All pre-existing and oxidation produced hydrogen was burned to the extent that oxygen is available.

The initial temperature of the NPP core melt was taken as $2700 \mathrm{~K}$ following Levy (1991). The temperature for the iron-alumina thermite mixture was taken as 2500 $\mathrm{K}$. Temperature for the corium simulant was taken as $2700 \mathrm{~K}$.

An energy to volume ratio of 5.84 was calculated for the $54,000 \mathrm{kgs}$ molten melt ejected at Zion. This is used to estimate the initial melt mass for the simulants off of the other plots. The results are shown in Table 2.7. Also shown is the melt volume to containment volume ratio. Table 2.8 shows the fractional contributions of each of the DCH contributors. 


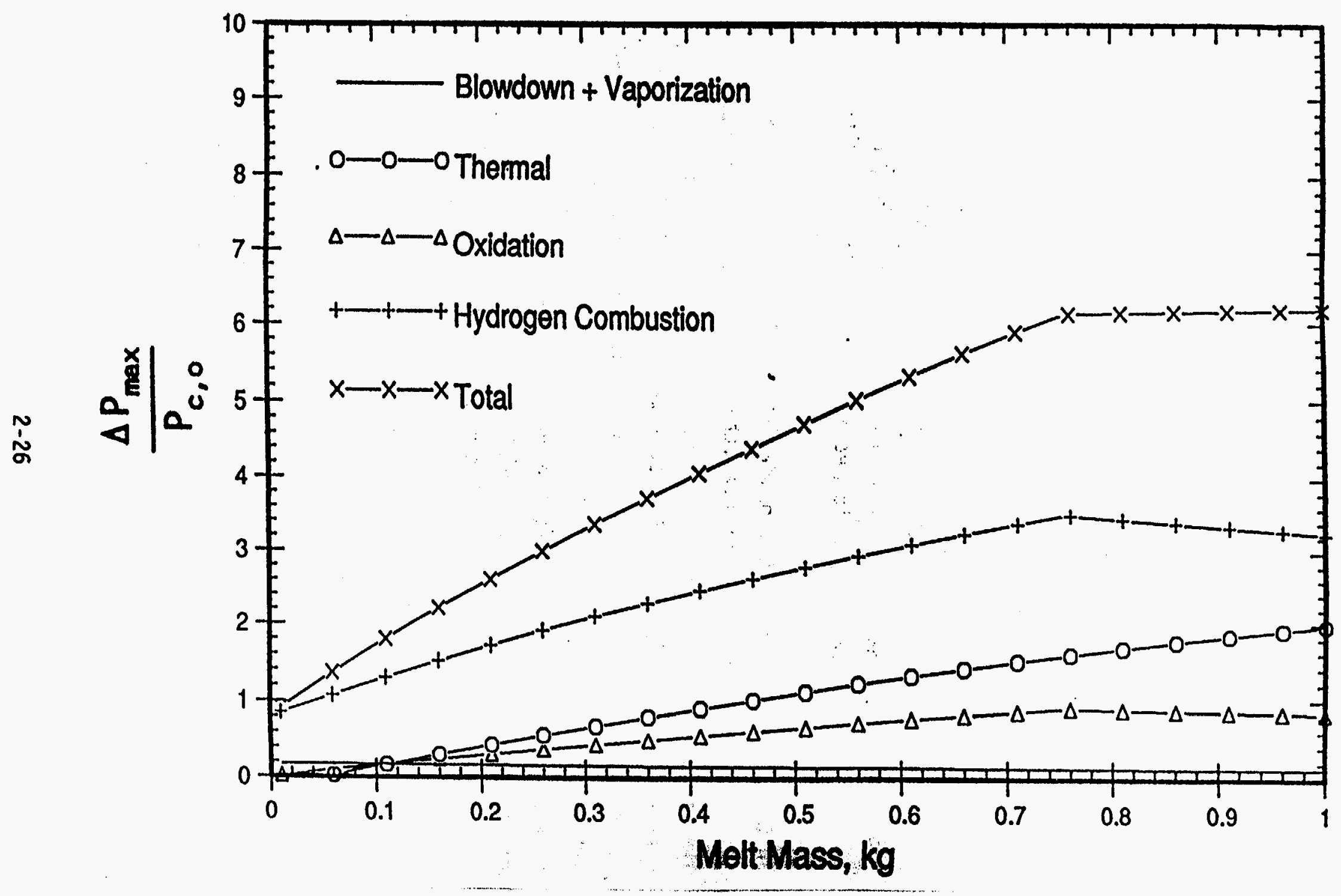




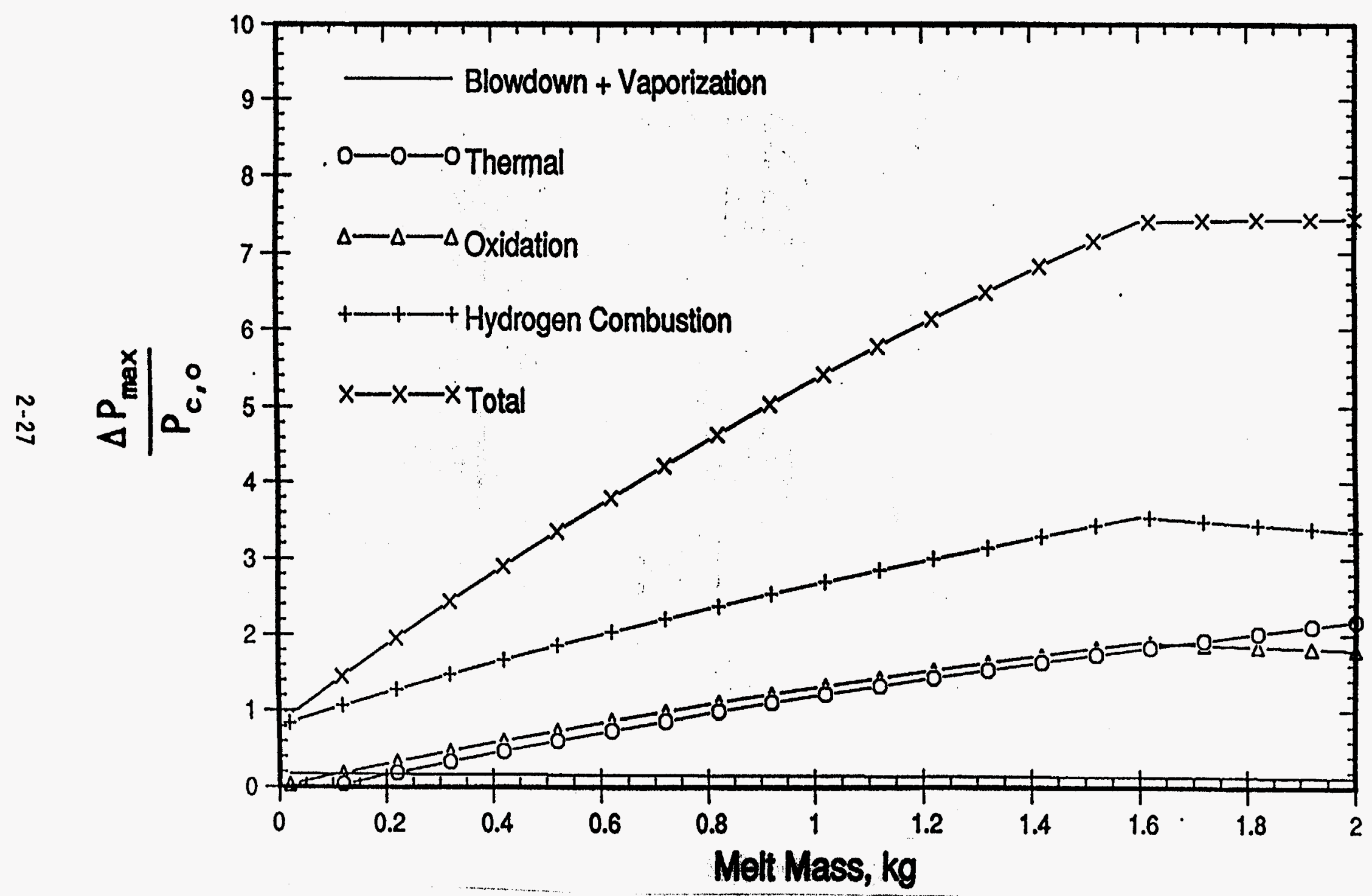


Table 2.6 Assumed Initial Conditions Used in Melt Mass Scaling Calculations

\begin{tabular}{|l|c|c|c|}
\hline & Reactor & $\begin{array}{c}\text { Expt. } \\
(2.55 \%)\end{array}$ & $\begin{array}{c}\text { Expt. } \\
\text { (Full Scale) }\end{array}$ \\
\hline$V_{\text {RCB }}, \mathrm{m}^{3}$ & 77,000 & 1.51 & 89,800 \\
\hline$V_{\text {RCS }}, \mathrm{m}^{3}$ & 360 & $6.1 \times 10^{-3}$ & 368 \\
\hline$P_{\text {CO }}, \mathrm{PPa}$ & 0.2 & 0.2 & 0.2 \\
\hline$T_{\text {CO }}, \mathrm{K}$ & 373 & 373 & 373 \\
\hline Atmospheres (Mole\%) & 50 & 50 & 50 \\
\hline Air & 46 & 46 & 46 \\
\hline Steam & 4 & 4 & 4 \\
\hline Hydrogen & 545,000 & 9.0 & 543,000 \\
\hline Moles of Steam in RCS & 144,000 & 3.0 & 180,930 \\
\hline Cavity Water Mass, Moles & \multicolumn{3}{|l}{} \\
\hline
\end{tabular}

Table 2.7 Required Melt Mass to Satisfy Energy/volume Scaling

\begin{tabular}{|l|c|c|c|}
\hline & $\Delta P / P_{c 0}$ & Mass $(\mathrm{Kg})$ & $V_{m} / V_{c}\left(\times 10^{-4}\right)$ \\
\hline $\mathrm{SASM}$ & 5.84 & 54,000 & 0.877 \\
\hline $\mathrm{Fe}-\mathrm{Al}_{2} \mathrm{O}_{3}$ & $n$ & 0.70 & 1.18 \\
\hline Corium & $"$ & 1.13 & 0.950 \\
\hline
\end{tabular}

Table 2.8 Fractional Contribution to DCH Load

\begin{tabular}{|l|c|c|c|}
\hline & SASM & $\mathrm{Fe}^{-\mathrm{Al}_{2} \mathrm{O}_{3}}$ & Corium \\
\hline \hline Blowdown & 0.267 & 0.0228 & 0.0243 \\
\hline Therma7 & 0.211 & 0.254 & 0.232 \\
\hline Oxidation & 0.246 & 0.147 & 0.249 \\
\hline $\mathrm{H}_{2}$ & 0.516 & 0.576 & 0.495 \\
\hline
\end{tabular}




\section{TEST SPECIFICATIONS AND INITIAL CONDITIONS}

Table 3.1 summarizes the initial conditions for DCH U2. Further details are given below.

\section{A. Melt Simulant}

The melt simulant for the present test is prototypic corium produced through a thermite type reaction. This experimental melt and the scaling analysis used to specify the initial mass was discussed in detail in chapter II. Table 3.1 gives the charge composition as mixed and loaded. The iron/alumina thermite mixture used in IET- 6 is given for reference.

\section{B. Expansion Vesse1 Atmosphere}

The vessel atmosphere initial condition was specified to be approximately the same as in IET-6. The atmosphere contains approximately 1 bar of air, 1 bar of nitrogen and $2.6 \mathrm{~mole} \%$ of pre-existing hydrogen. The hydrogen amount corresponds to approximately $50 \%$ in-vessel oxidation of zircaloy. The exact composition is shown in Table 3.1. The initial pressure was $0.20 \mathrm{MPa}$ and the temperature $300 \mathrm{~K}$ in both tests.

\section{Cavity Water}

The amount of water pre-existing in the cavity was 55 grams in all tests. This corresponds to a pool height of $2.9 \mathrm{~mm}$. Thus, in reality this can be considered a damp cavity.

D. Hole Diameter

The initial hole diameter is $11 \mathrm{~mm}$. This diameter is fixed by the LAVA hemisphere.

\section{E. Driving High Pressure Steam}

The steam driving pressure was specified as $6.2 \mathrm{MPa}$ for the test. However, due to steam condensation problems, the driving pressure was $4.25 \mathrm{MPa}$. The condensation occurred due to a low initial temperature of the MGI. The melt generator was kept at low temperature because spontaneous ignitions of the uranium powders had been occurring during the pre-test MGI heating. Due to this difficulty U1B was run with an internal trace heater in the MGI as shown in 
Figure 2.4. This somewhat reduced the condensation problem resulting in driving pressure of $6.0 \mathrm{MPa}$ in U1B. However, a monitoring thermocouple during the heat up phase in $\mathrm{U} 2$ indicated that the thermite charge was heating up to the point where a spontaneous ignition could occur. Thus, it was decided to run the test before all of the structure in the MGI could be heated to the desired pre-test temperature. 
Table 3.1 Initial Conditions

\begin{tabular}{|l|c|c|}
\hline \multicolumn{1}{|c|}{ Thermite Charge } & U2 & IET-6 \\
\hline Iron Oxide, g & 232 & 485 \\
\hline Chromium Oxide, g & 80 & $-\ldots-$ \\
\hline Aluminum, g & $-\cdots--$ & 151 \\
\hline Chromium, g & $\cdots-.-$ & 77 \\
\hline Uranium, g & 575 & $\cdots--$ \\
\hline Zirconium, g & 243 & $-\cdots$ \\
\hline Total & 1130 & 713 \\
\hline \hline Hole Diameter, mm & 11 & 11 \\
\hline Driving Pressure, MPa & 4.25 & 6.6 \\
\hline Blowdown Moles, g-moles & 5.89 & 9.65 \\
\hline EV Initial Pressure, MPa & 0.20 & 0.20 \\
\hline EV Initial Temperature, $\mathrm{K}$ & 300 & 310 \\
\hline EV Atmosphere, mole \% & & \\
$\mathrm{H}_{2}$ & 2.6 & 2.0 \\
$\mathrm{O}_{2}$ & 11.6 & 9.9 \\
$\mathrm{~N}_{2}$ & 84.6 & 87.5 \\
\hline
\end{tabular}




\section{EXPERIMENTAL RESULTS}

A. Blowdown History

The blowdown pressure histories for $U 2$ is shown in Figure 4.1. The plot shows the large decrease in accumulator pressure when the valve was opened due to condensation. Figure 4.2 compares the blowdown in U2 and IET-6. The lower driving pressure in $\mathrm{U} 2$ is noted. The potential effect that this had on the results is discussed here. The blowdown time in this test was somewhat distorted in U2. For an ideal gas in a fixed volume, $V_{R C S}$, blowing down isothermally through a hole of area, $A_{H}$, the pressure will be given by

$$
P=P_{0} e^{t / \tau_{2}}
$$

The blowdown time is given by

$$
\tau_{S}=\frac{V_{R C S}}{C_{d} A_{H} \sqrt{R T_{0}}}
$$

where $R$ is the ideal gas constant and $T_{0}$ is the gas temperature. Fitting equation (4-1) to the blowdown traces yielded values of 0.49 seconds and 0.30 seconds for U2 and IET-6, respectively.

Examination of the blowdown data indicates that the longer time scale obtained in $U 2$ is partially due to vaporization of some condensed steam during the blowdown. The number of additional steam moles that could have been added due to vaporization may have been considerable. However, since the accumulator initial conditions prior to opening the valve in U2 and IET-6 where approximately the same, the total number of moles potentially added to the vessel is the same. In addition a significant portion of the condensed steam is vaporized and added late in the blowdown. Therefore, the extra steam would not be coherent with the cavity sweepout. The effect of the addition of initially condensed steam moles on the DCH load is small since it is not coherent with the sweepout. However, a phenomenological model recently developed by Binder (1993) finds that the DCH load is sensitive to initial driving pressure. This result is obtained because higher pressures produce higher cavity velocities and subsequently larger entrainment rates. Thus, the model predicts a larger DCH load at a driving pressure of $6.6 \mathrm{MPa}$ compared to $4.3 \mathrm{MPa}$ with all other parameters being equal. 


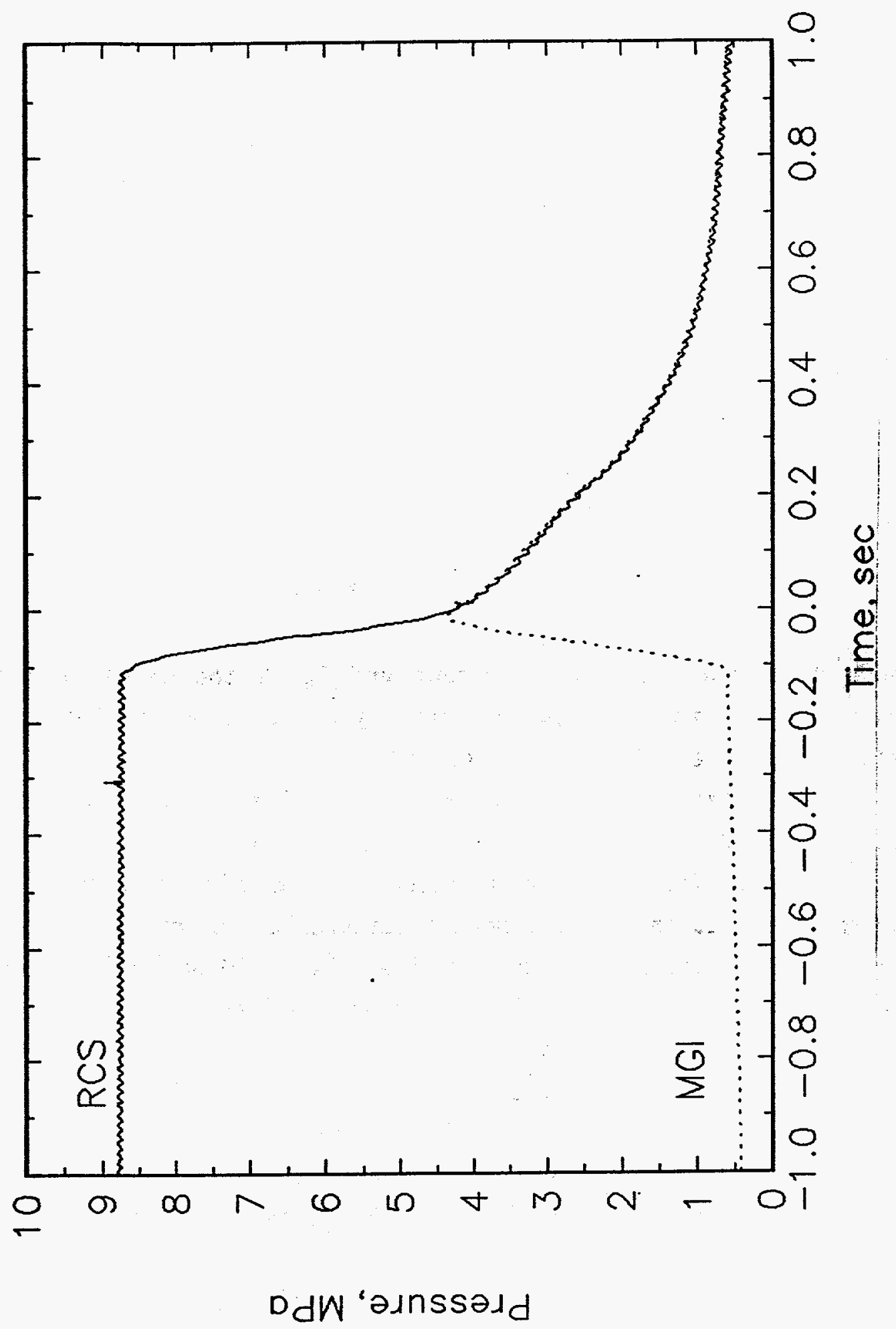




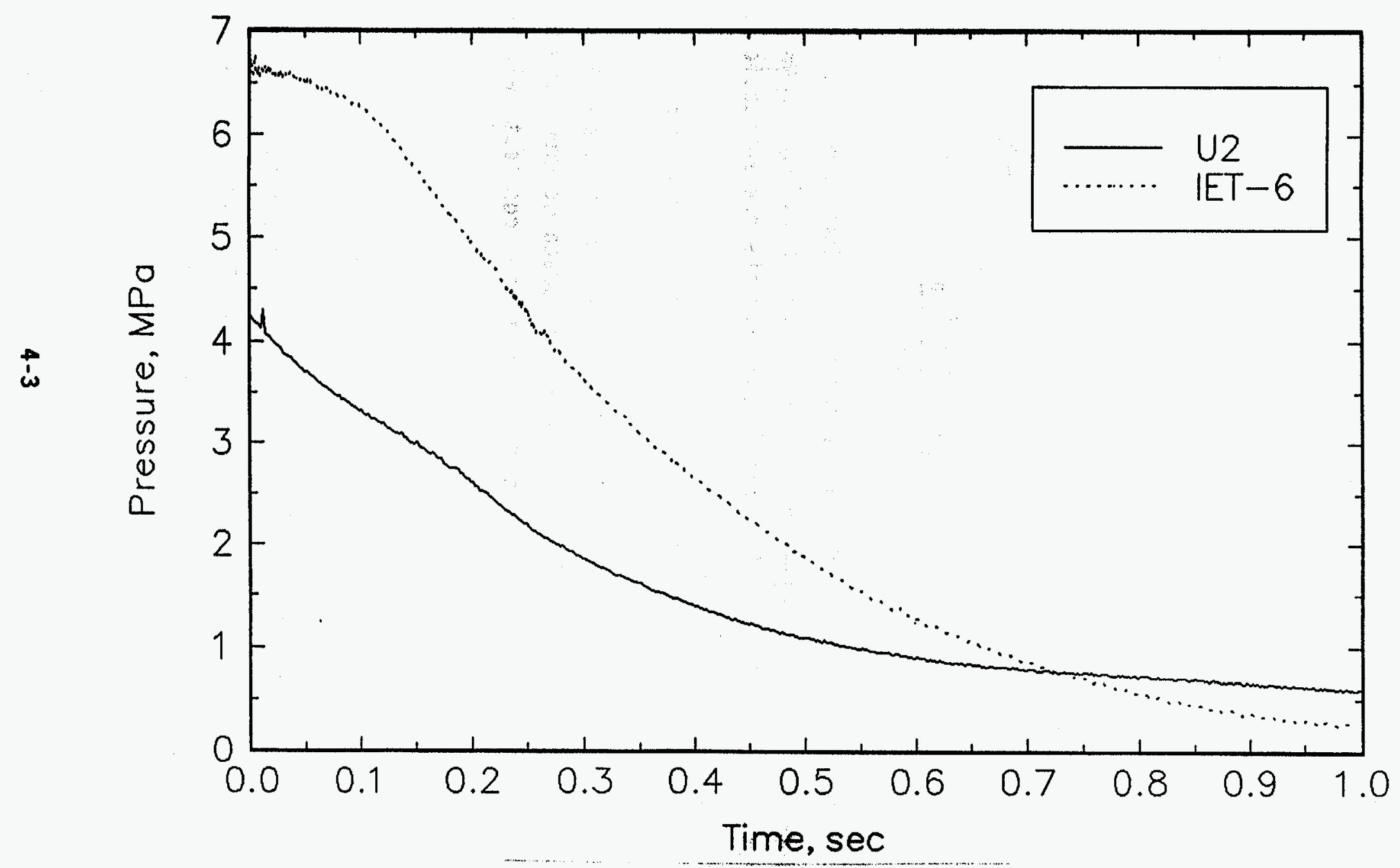


Therefore, the IET-6 and U2 tests can not be considered true counterpart tests. However, it is still useful to compare the results.

\section{B. Pressure Measurements}

The containment pressure is given in dimensional form in Figure 4.3. The peak pressure obtained in the tests were 186 and $250 \mathrm{kPa}$ for U2 and IET-6, respectively. It is also noted that an inflection in the containment pressure was obtained in U2 near 2.0 seconds. This second peak is associated with a hydrogen burn that continued in the upper dome after the vessel blowdown neared completion. The flame from this burn is partially visible in the HYCAM and video recording made during the tests. A second comparison of the containment pressure is made by scaling the variables as suggested by Pilch (1992). Time is scaled with the blowdown time, $\tau_{s}$, and the pressure is scaled as follows:

$$
P_{c}^{*}=\frac{P_{c}-P_{c, 0}}{\Delta P_{c, \max }}
$$

where $\Delta P_{c, \max }$ is the calculated adiabatic maximum pressure increase. This calculation is given in Chapter $V$. The non-dimensional containment pressure plot is given in Figure 4.4. This plot shows that the pressurization efficiency was slightly larger in IET-6.

The cavity pressure history for $U_{2}$ is given in Figure 4.5. The output of the photocell positioned at the cavity exit window is also plotted on this figure. The pressure difference between the containment and the cavity occurred due to debris sweepout. The duration of this sweepout interval and the magnitude of the difference was less than obtained in previous tests with higher driving pressure.

\section{Temperature Measurements}

The thermocouple which is used to measure the gas temperature in the cavity failed in this test.

Figure 4.6 plots the subcompartment gas temperatures. The thermocouples located on the cavity exit side indicate increases that correlate with blowdown and cavity sweepout. Thermocouple TC8-10 shows an increase from zero to one second, followed be a plateau from 1 to 1.75 seconds, followed by a second peak. 


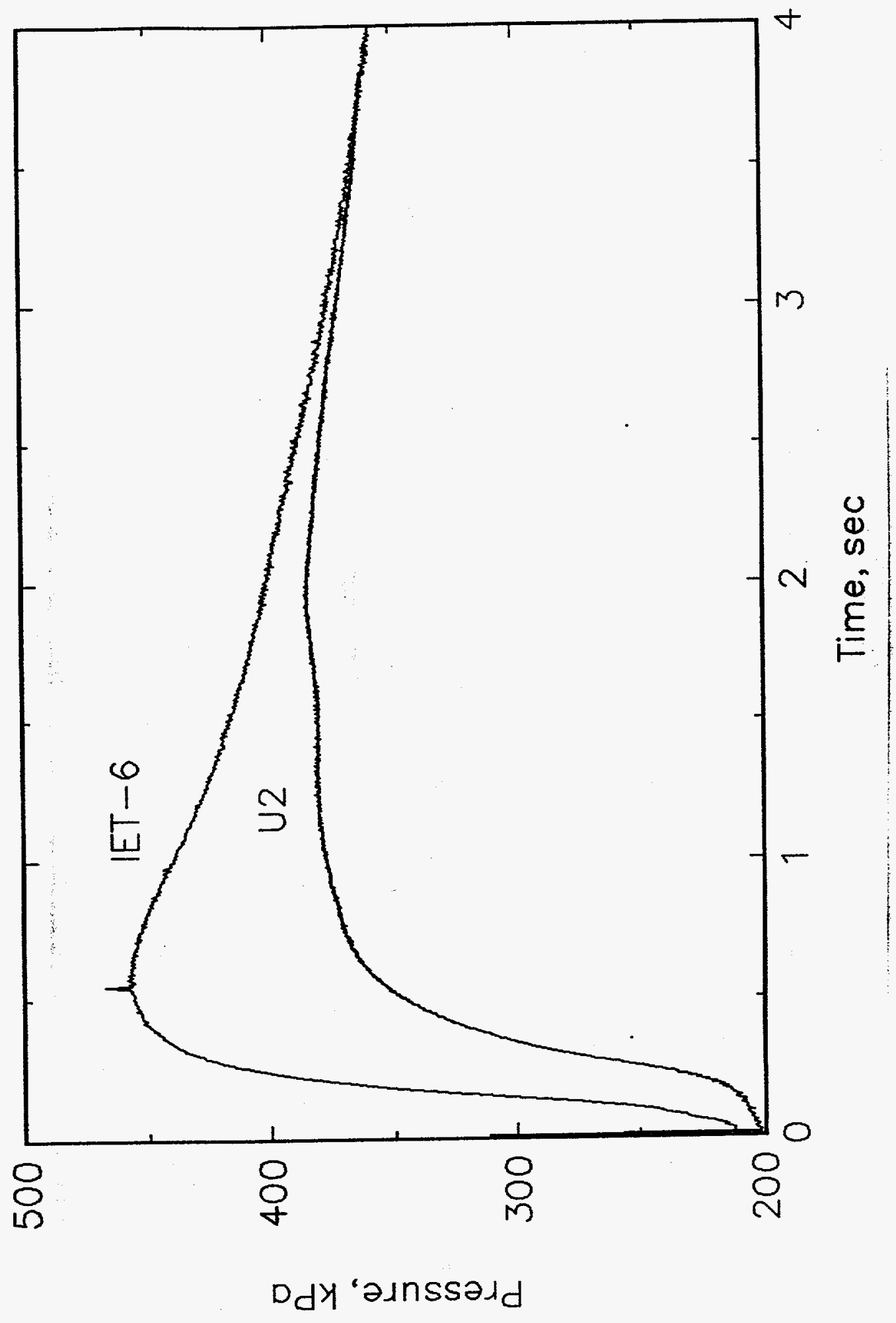

4-5 


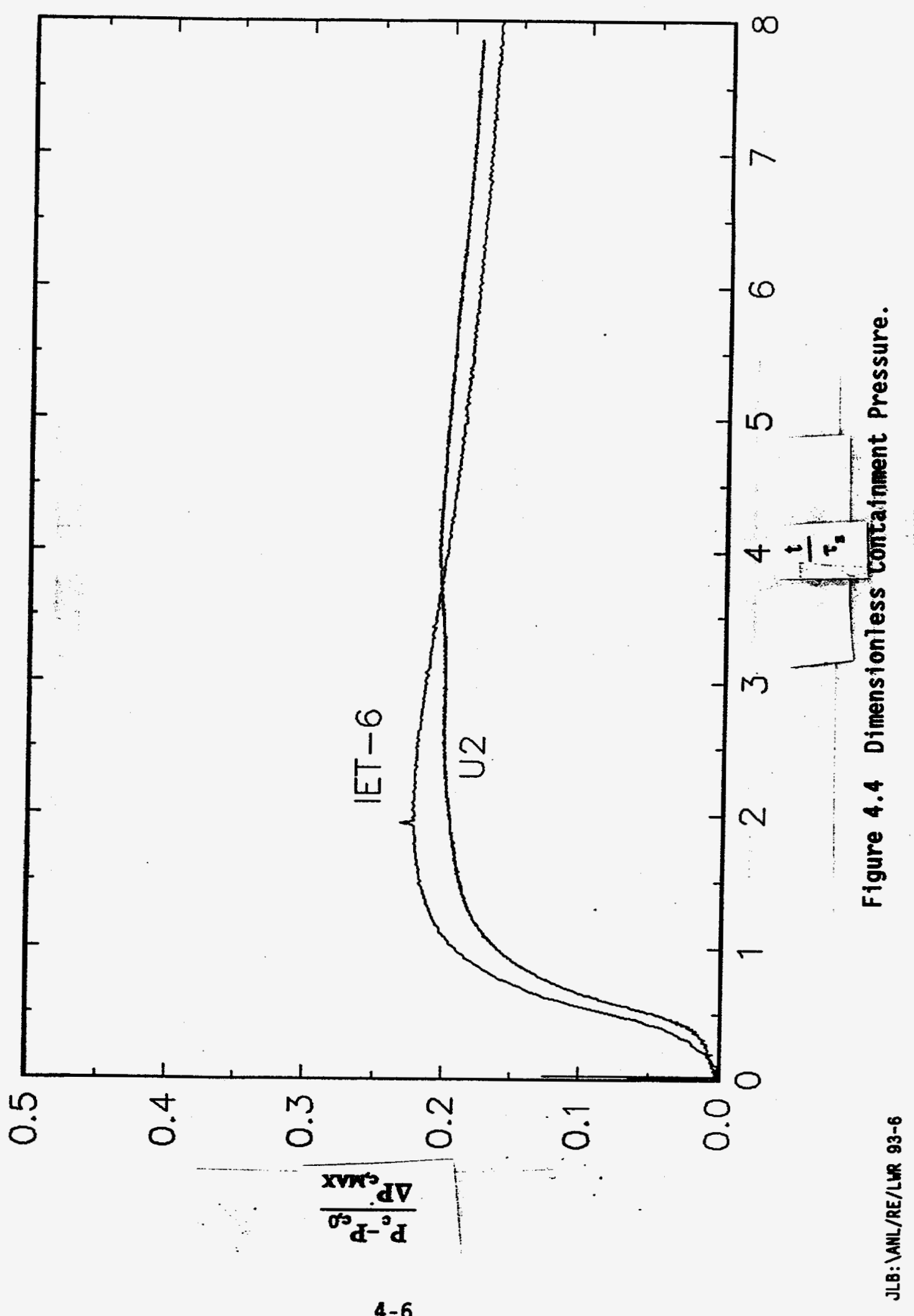




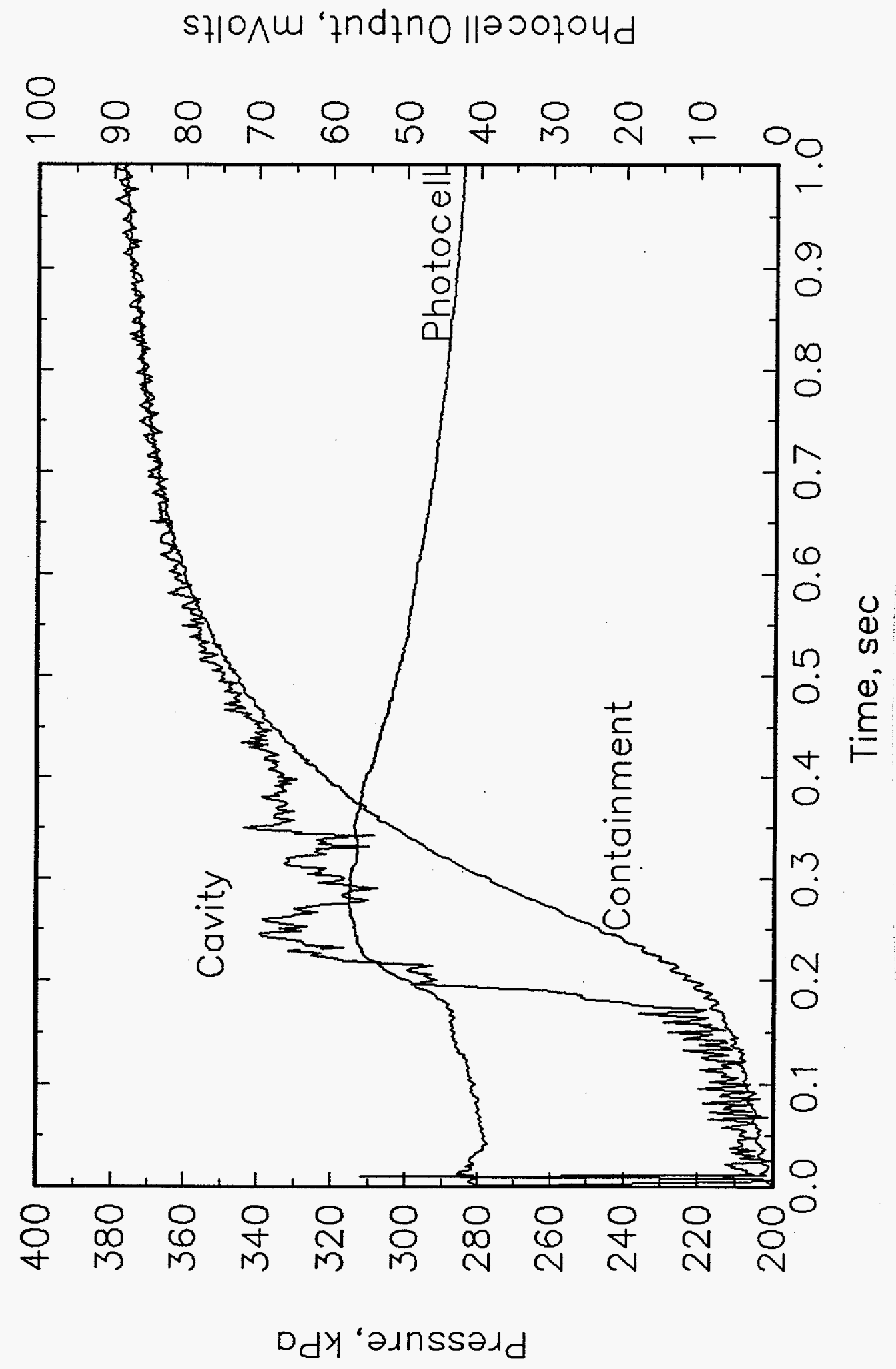

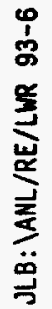




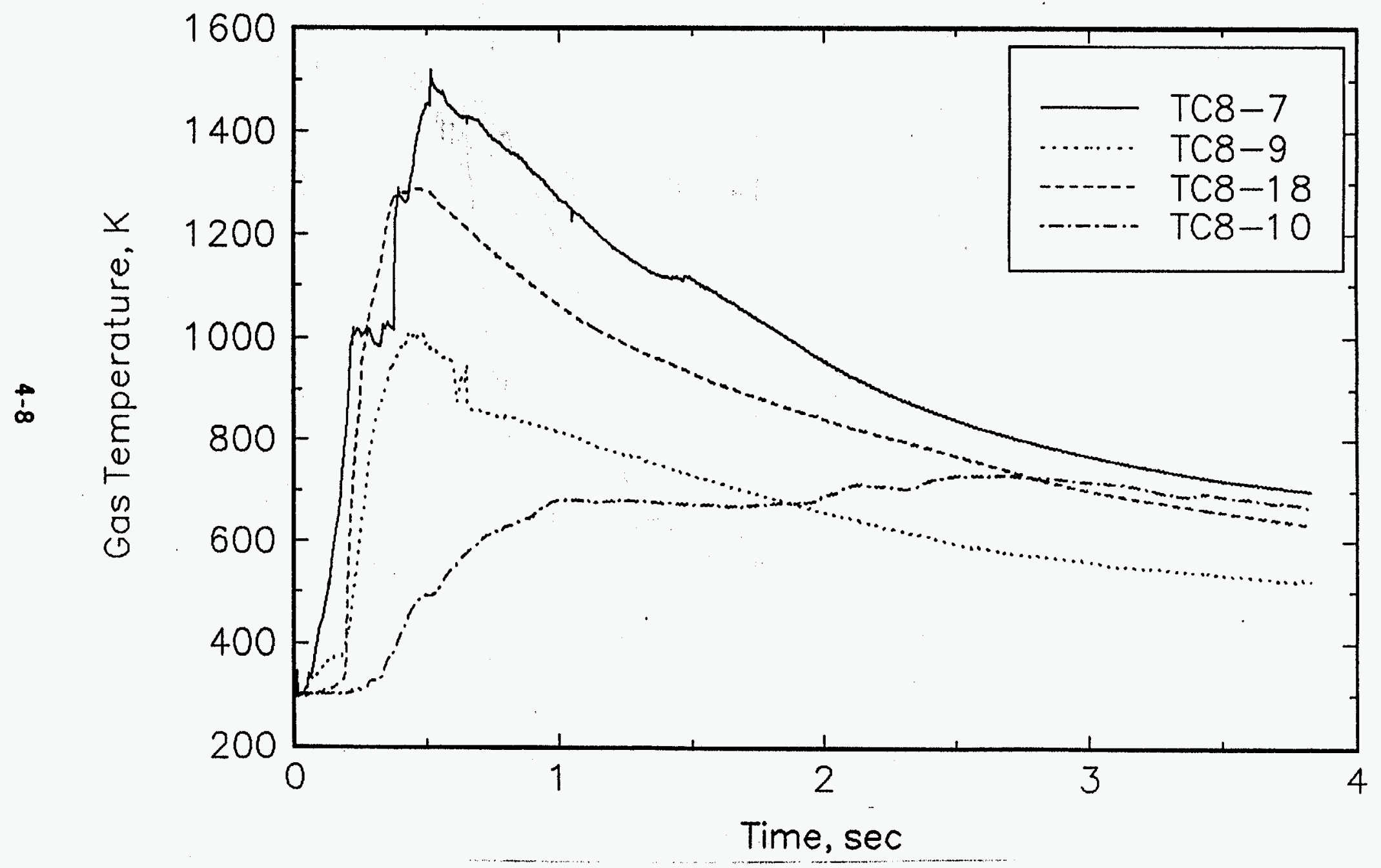


This second peak correlates with the second peak obtained in the containment pressure.

Figure 4.7 plots the containment pressure and gas temperature at various elevations above the operating deck. The highest gas temperature is obtained at the 1.2 meters elevation. This thermocouple is in the direct path of the jet exiting the subcompartment.

\section{Gas Sample Measurements}

Hydrogen production and oxygen depletion was measured by gas sampling at various locations and times as given in Table 2.2. Table 4.1 gives the results of the gas bottle analysis.

Bottles 2 and 3 in the cavity indicate high hydrogen concentrations at 15.0 and 60.0 seconds after the start of the HPME. In previous tests gas samples were taken in the cavity during the sweepout phase. This data showed the expected high concentrations of hydrogen. This was the first test in which gas samples were taken in the cavity after the sweepout. Therefore, it is difficult to interpret this data. Interpretation is further complicated by the fact that the samples could have contained moles of steam which were condensed at the time of analysis. However, it appears that hydrogen is unequally distributed after the blowdown, with larger concentrations occurring in the cavity. In addition, there is some indication that the debris/steam reactions continue in cavity after blowdown. Figure 4.8 plots the hydrogen and oxygen concentrations as a function of time after the HPME. The same approximate behavior is noted for IET-6 and U2. These results were converted to the number of hydrogen and oxygen moles by using the ideal gas law to calculate the total number of gas moles in the expansion vessel. Figure 4.9 plots number of moles oxygen and hydrogen after the test. The hydrogen combustion phenomena is the same for the corium as it was in the iron/alumina tests. Hydrogen produced in the cavity during sweepout was burned as a jet exiting the subcompartment structures. However, the pre-existing hydrogen did not burn in either test. Assuming that all of the oxygen depleted in the test was due to hydrogen combustion a total of $6.0 \mathrm{~g}$-moles of hydrogen was produced and $6.0 \mathrm{~g}$-moles were burned. This is contrasted with $4.9 \mathrm{~g}$-moles of hydrogen produced and $4.2 \mathrm{~g}$-moles burned in IET-6. The 1arger hydrogen production with corium is consistent with the findings in U1A and U1B. 


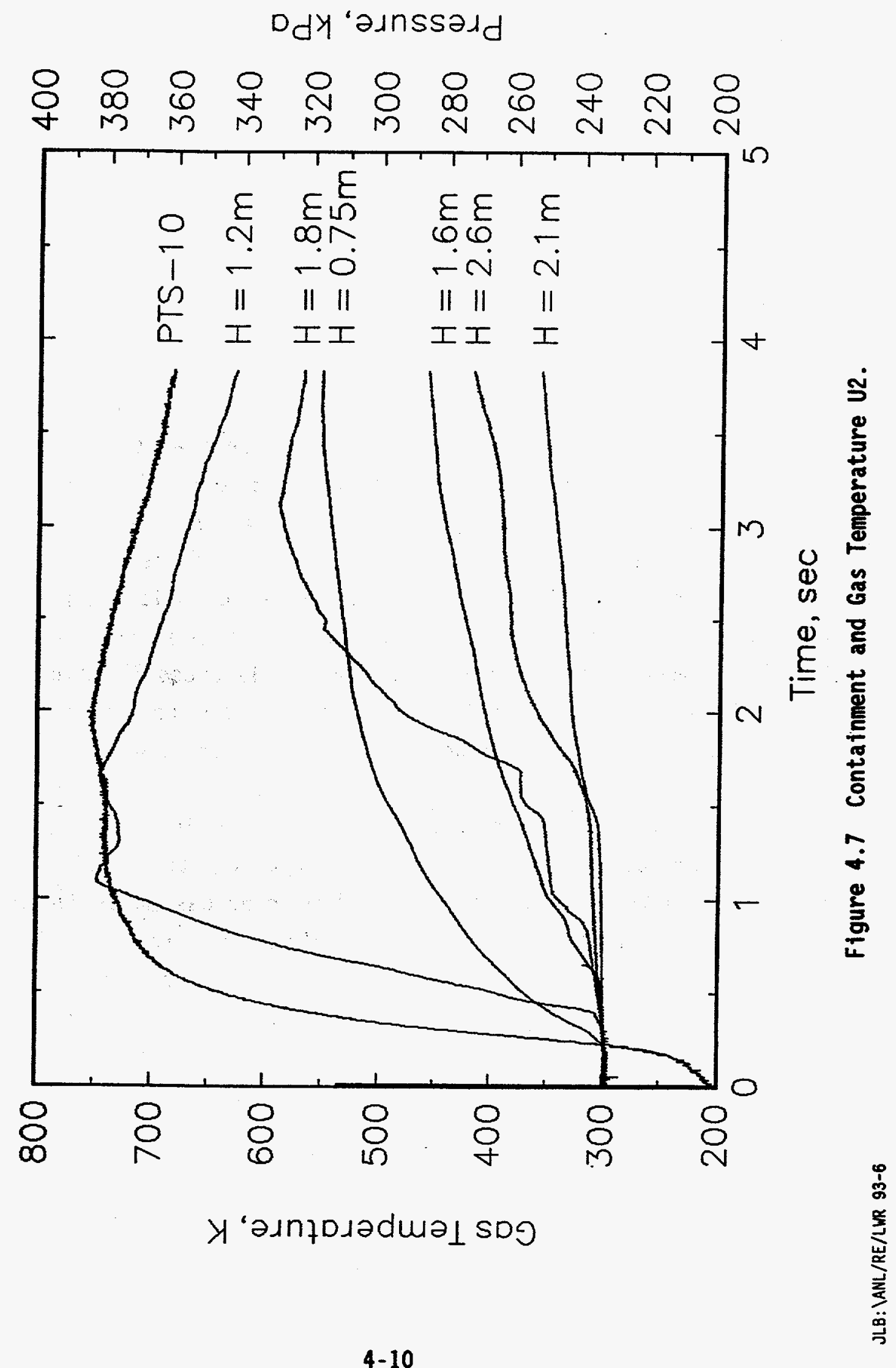


Table 4.1 Results of gas bottle analysis

\begin{tabular}{|c|c|c|c|}
\hline Bottle \# & $\mathrm{N}_{2}, \mathrm{~mol} \%$ & $\mathrm{H}_{2}$, mol\% & $\mathrm{O}_{2}, \mathrm{mol \%}$ \\
\hline 1 & \multicolumn{3}{|c|}{ Breached } \\
\hline 2 & $74.5 \pm 0.9$ & $5.4 \pm 0.3$ & $9.9 \pm 0.2$ \\
\hline 3 & $65.6 \pm 0.8$ & $18.2 \pm 1.1$ & $8.1 \pm 0.2$ \\
\hline 4 & \multicolumn{3}{|c|}{ Breached } \\
\hline 5 & $84.6 \pm 0.6$ & $2.6 \pm 0.1$ & $11.6 \pm 0.3$ \\
\hline 6 & $86.3 \pm 0.6$ & $2.6 \pm 0.1$ & $9.2 \pm 0.2$ \\
\hline 7 & $86.1 \pm 0.6$ & $2.6 \pm 0.1$ & $9.5 \pm 0.2$ \\
\hline 8 & $86.4 \pm 0.6$ & $2.4 \pm 0.1$ & $9.3 \pm 0.2$ \\
\hline 9 & $85.4 \pm 0.7$ & $2.4 \pm 0.1$ & $10.3 \pm 0.3$ \\
\hline 10 & $86.0 \pm 0.6$ & $2.6 \pm 0.1$ & $9.4 \pm 0.2$ \\
\hline 11 & $85.3 \pm 0.8$ & $2.5 \pm 0.2$ & $10.6 \pm 0.3$ \\
\hline 12 & $85.6 \pm 0.6$ & $2.4 \pm 0.1$ & $10.2 \pm 0.3$ \\
\hline 13 & $85.6 \pm 0.9$ & $2.4 \pm 0.2$ & $10.4 \pm 0.4$ \\
\hline 14 & $87.0 \pm 0.6$ & $3.1 \pm 0.2$ & $8.0 \pm 0.2$ \\
\hline 15 & $87.2 \pm 0.6$ & $3.0 \pm 0.2$ & $7.9 \pm 0.2$ \\
\hline 16 & $87.1 \pm 0.9$ & $2.9 \pm 0.3$ & $8.2 \pm 0.3$ \\
\hline 17 & $87.7 \pm 0.7$ & $2.7 \pm 0.2$ & $7.8 \pm 0.2$ \\
\hline 18 & $87.4 \pm 0.6$ & $2.8 \pm 0.2$ & $8.2 \pm 0.2$ \\
\hline
\end{tabular}




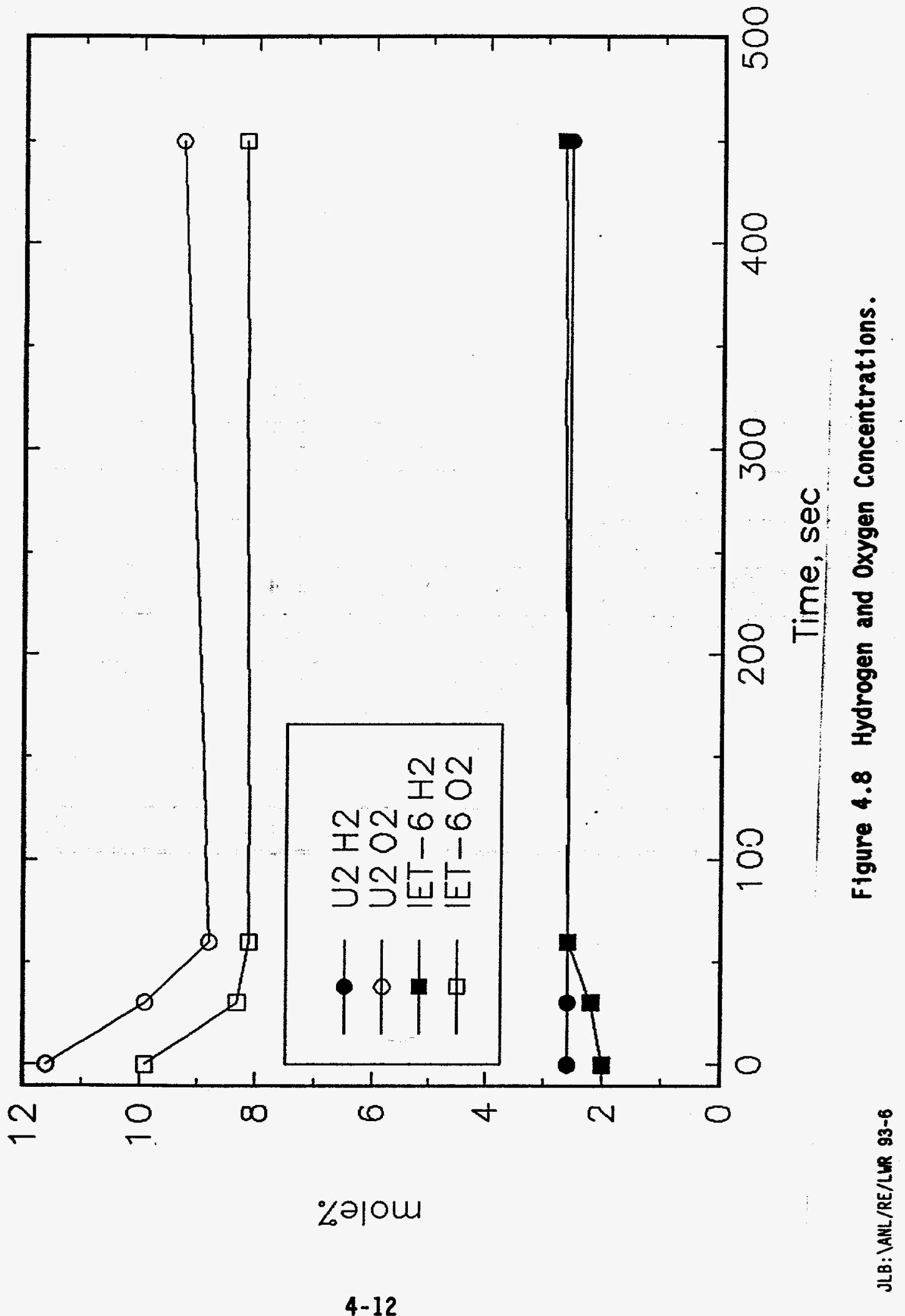




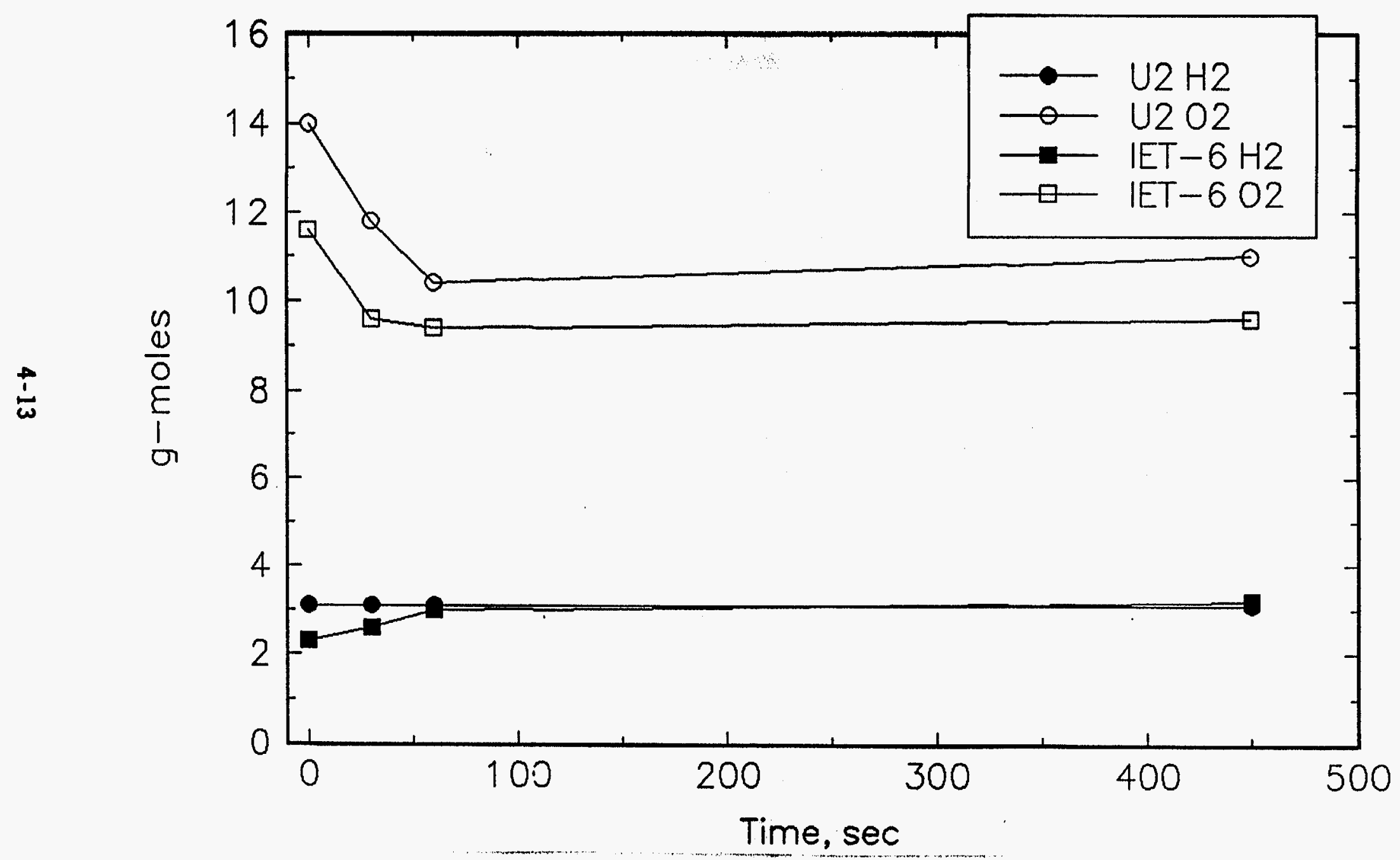

Figure 4.9 Hydrogen and Oxygen Moles. 


\section{E. Debris Disposition}

The post-test debris disposition is summarized in Table 4.2. The fraction dispersed from the cavity is 0.295 for U2. This is contrasted with higher dispersal fractions obtained in U1B and IET-6. The lower dispersed fraction at lower driving pressure is consistent with the UIA test findings. 
Table 4.2 Debris Recovery Results.

\begin{tabular}{|l|c|c|c|c|}
\hline \multicolumn{1}{|c|}{ Location/Mass Balance, grams } & U1A & U1B & U2 & IET-6 \\
\hline A. Initial Thermite Charge & 1130.0 & 1130.0 & 1130.0 & 713.0 \\
\hline B. MGI & 53.2 & 50.0 & 23.3 & 30.3 \\
\hline C. Cavity and Chute & 898.3 & 169.5 & 820.4 & 262.7 \\
\hline D. Seal table Room & 80.4 & 167.9 & 0.0 & 167.9 \\
\hline E. Remaining Subcompartment & 60.0 & 636.2 & 343.8 & 339.6 \\
\hline F. Total in Subcompartment $=\mathrm{D}+\mathrm{E}$ & 140.4 & 804.1 & 343.8 & 507.5 \\
\hline G. Upper Dome & 73.7 & 48.5 & 0.0 & 81.3 \\
\hline H. Total $=$ B + C + F + G & 1165.6 & 1072.0 & 1187.5 & 881.8 \\
\hline \multicolumn{1}{|c|}{ Transport Fractions } & & & & \\
\hline Fraction Ejected Into Cavity $=1-$ & 0.953 & 0.956 & 0.979 & 0.966 \\
\hline Fraction Dispersed $=(\mathrm{F}+\mathrm{G}) /(\mathrm{C}+\mathrm{F}+\mathrm{G})$ & 0.19 & 0.795 & 0.295 & 0.691 \\
\hline Fraction to Upper Dome $=\mathrm{F} /(\mathrm{F}+\mathrm{G})$ & 0.34 & 0.057 & 0.0 & 0.138 \\
\hline
\end{tabular}

${ }^{1}$ These measurements are assumed to be only order of magnitude correct. This is due to a large fraction of the recovered particulate being made up of concrete, paint and other contaminants. 


\section{ENERGY BALANCE AND PRESSURIZATION EFFICIENCY}

This section details the adiabatic energy balance for the test and the experimentally obtained pressurization efficiency. The approach to the energy balance is the same as detailed in Chapter II for establishing the initial melt mass. Table 5.1 gives the results of the energy balance equation. The number of steam moles that were assumed to participate in the process were taken from the accumulator initial conditions at the time of melt plug failure. Thus, less moles are indicated for UIA and U2. The efficiencies obtained in the inerted tests were considerably lower for corium compared to the iron/alumina thermite. The difference in the pressurization efficiency is not as pronounced for the noninerted tests U2 and IET-6 despite the lower pressure in U2. The reason for this is the chemical energy contained in the corium as elaborated on in Chapter II. 
Table 5.1 Energy Balance and Pressurization Efficiency

\begin{tabular}{|c|c|c|c|c|c|}
\hline & UIA & U1B & IET-1RR & U2 & IET-6 \\
\hline $\begin{array}{l}\text { Debris specific heat, } C_{d} \text {, } \\
\mathrm{J} / \mathrm{kg}-\mathrm{K}\end{array}$ & 500 & 500 & 978 & 500 & 978 \\
\hline $\begin{array}{l}\text { Containment atmosphere } \\
\text { specific heat, } C_{v}, \mathrm{~J} / \mathrm{kg}-\mathrm{K}\end{array}$ & 20.8 & 20.8 & 20.8 & 20.8 & 20.8 \\
\hline Mass of debris, $M_{d}$, $\mathrm{kg}$ & 1.130 & 1.130 & 0.820 & 1.130 & 0.713 \\
\hline $\begin{array}{l}\text { Blowdown gas moles, } N_{b} \text {, } \\
\text { g-moles }\end{array}$ & 4.18 & 8.87 & 9.84 & 5.89 & 9.65 \\
\hline $\begin{array}{l}\text { Containment gas moles, } N_{0}, \\
g \text {-moles }\end{array}$ & 113 & 126 & 126 & 126 & 113 \\
\hline Heat capacity ratio, $\phi$ & 0.21 & 0.20 & 0.30 & 0.21 & 0.25 \\
\hline $\begin{array}{l}\text { Containment pressure, } \mathrm{P}_{\mathrm{c}, 0} \text {, } \\
\mathrm{MPa}\end{array}$ & 0.2 & 0.2 & 0.2 & 0.2 & 0.2 \\
\hline $\begin{array}{l}\text { Energy source due to } \\
\text { addition of blowdown steam, } \\
\Delta E_{B} \text {, MJ }\end{array}$ & 0.049 & 0.098 & 0.092 & 0.069 & 0.098 \\
\hline $\begin{array}{l}\text { Energy source due to debris } \\
\text { thermal energy, } \Delta E_{T}, \text { MJ }\end{array}$ & 1.35 & 1.35 & 1.56 & 1.35 & 1.55 \\
\hline $\begin{array}{l}\text { Energy source due to debris } \\
\text { oxidation, } \Delta E_{R}, M J\end{array}$ & 0.66 & 1.33 & 0.74 & 0.93 & 0.73 \\
\hline $\begin{array}{l}\text { Energy source due to } \\
\text { hydrogen combustion, } \Delta E_{\mathrm{H} 2} \text {, } \\
\text { MJ }\end{array}$ & 0 & 0 & 0 & 2.20 & 2.88 \\
\hline $\begin{array}{l}\text { Calculated maximum pressure } \\
\text { rise, } \Delta \mathrm{P}_{\max }, \mathrm{MPa}\end{array}$ & 406 & 552 & 479 & 895 & 1,110 \\
\hline $\begin{array}{l}\text { Pressurization Efficiency, } \\
\eta=\Delta P_{\text {MEAS }} / \Delta P_{\operatorname{mx}}\end{array}$ & 10.3 & 20.8 & 31.3 & 20.6 & 22.6 \\
\hline
\end{tabular}




\section{SUMMARY}

Integral DCH experiments in 1/40th scale Zion Nuclear Power Plant geometry using prototypic core materials have been completed. The tests were conducted in order to address questions regarding the non-prototypic behavior of iron/alumina thermite as a core melt simulant. Iron/alumina thermite was used in the IET counterpart tests conducted at ANL and SNL. This document reports on the second test, U2. The results of the U1A, UIB, IET-1RR, U2 and IET-6 are summarized in Table 6.1.

Table 6.1 Summary of the Test Results

\begin{tabular}{|c|c|c|c|c|c|}
\hline & U1A & U1B & IET-1RR & U2 & IET-6 \\
\hline Driving Pressure, $\mathrm{P}_{0}, \mathrm{MPa}$ & 3.0 & 6.0 & 6.7 & 4.3 & 6.6 \\
\hline Blowdown Time, $\tau_{s}$, sec & 0.38 & 0.54 & 0.23 & 0.49 & 0.28 \\
\hline Amount of Blowdown Steam, & 4.18 & 8.87 & 9.84 & 5.89 & 9.65 \\
\hline Initial Melt Mass, $\mathrm{kg}$ & 1.130 & 1.130 & 0.820 & 1.130 & 0.713 \\
\hline Initial Containment & 0.2 & 0.2 & 0.2 & 0.2 & 0.2 \\
\hline \multicolumn{6}{|c|}{ Initial Containment Atmosphere Composition, mole\% } \\
\hline $\mathrm{H}_{2}$ & 0.0 & 0.0 & 0.0 & 2.6 & 2.0 \\
\hline $\mathrm{O}_{2}$ & 0.12 & 0.57 & 0.47 & 11.6 & 9.9 \\
\hline $\mathrm{N}_{2}$ & 99.9 & 99.0 & 99.0 & 84.6 & 87.5 \\
\hline$\Delta P_{\text {MUX, CAVITY }}, \mathrm{KPa}$ & 90 & 400 & 550 & 185 & 480 \\
\hline$\Delta \mathrm{P}_{\text {max, contaimment }}, \mathrm{kPa}$ & 45 & 111 & 150 & 185 & 250 \\
\hline Sweepout Fraction & 0.190 & 0.795 & 0.705 & 0.295 & 0.691 \\
\hline $\mathrm{H}_{2}$ Pre-Existing, g-moles & 0 & 0 & 0 & 3.1 & 2.3 \\
\hline $\mathrm{H}_{2}$ Produced, g-moles & 5.0 & 6.0 & 4.1 & 6.0 & 4.9 \\
\hline $0_{2}$ Depleted, g-moles & $\cong 0$ & $\simeq 0$ & $\simeq 0$ & 3.0 & 2.1 \\
\hline Pressurization Efficiency & 10.3 & 20.8 & 31.3 & 20.6 & 22.6 \\
\hline
\end{tabular}


The initial melt mass was selected to match an energy to volume scaling as described in Chapter II. This was the same approach used to specify the thermite mass for the IET tests. The UIA, U1B and U2 tests employed the same geometry as the IET tests. The U2 test was specified with an initial containment atmosphere similar to IET-6. The driving pressure in U2 was $4.25 \mathrm{MPa}$. The sweepout fraction from the cavity was $\mathbf{0 . 2 9 5}$. The peak pressure rise measured in the containment was $186 \mathrm{kPa}$. A total of $3.1 \mathrm{~g}$-moles of hydrogen were pre-existing in the containment. A total of $6.0 \mathrm{~g}$-moles of hydrogen were produced and $6.0 \mathrm{~g}$ moles were calculated to have combusted. This assumes all measured oxygen depletion occurred due to hydrogen re-combination. 


\section{REFERENCES}

Allen, M. D., M. M. Pilch, R. T. Nichols and R. 0. Griffith, "Experiments to Investigate the Effect of Flight Path on Direct Containment Heating (DCH) in the Surtsey Test Facility," NUREG/CR-5728, 1991.

Baker, L., Personal Communication, 1993.

Binder, J. L., "A Model for the Prediction of DCH Loads," to be published.

Binder, J. L., L. M. McUmber and B. W. Spencer, "Quick Look Data Report on the Integral Effects Test 1RR In The COREXIT Facility at Argonne National Laboratory," ANL Report ANL/RE/LWR 92-3, May 1992.

Binder, J. L., L. M. McUmber and B. W. Spencer, "Quick Look Data Report on the Integral Effects Test 6 In The COREXIT Facility at Argonne National Laboratory," ANL Report ANL/RE/LWR 92-8, August, 1992.

Binder, J. L., L. M. McUmber and B. W. Spencer, "Direct Containment Heating Experiments in Zion Nuclear Power Plant Geometry Using Prototypic Materials: The UIA and U1B Tests," ANL Report ANL/RE/LWR 93-3, Apir1 1993.

Levy, S., Appendix $G$ in "An Integrated Structure and Scaling Methodology for Sever Accident Technical Issue Resolution," NUREG/CR-5809, EGG-2659, 1991.

Pilch, M. M., M. D. Allen, "A Scaling Methodology for Direct Containment Heating with Application to the Design and Specification of an Experiment Program for Resolving DCH Issues," SAND 91-2784, 1991. 